\title{
Recent changes in Pan-Arctic sea ice, lake ice, and snow on/off timing
}

\author{
Alicia A. Dauginis ${ }^{1}$, Laura C. Brown ${ }^{1}$ \\ ${ }^{1}$ Department of Geography, University of Toronto Mississauga, L5L 1C6, Canada \\ Correspondence to: LC Brown (1c.brown@utoronto.ca)
}

\begin{abstract}
Arctic snow and ice cover are vital indicators of climate variability and change, yet while the Arctic shows overall warming and dramatic changes in snow and ice cover, the response of these high-latitude regions to recent climatic change varies regionally. Although previous studies have examined changing snow and ice separately, examining phenology changes

10 across multiple components of the cryosphere together is important for understanding how these components, and their response to climate forcing, are interconnected. In this work, we examine recent changes in sea ice, lake ice and snow together at the pan-Arctic scale using the Interactive Multisensor Snow and Ice Mapping System 24 km product from 1997 - 2019, with a more detailed regional examination from $2004-2019$ using the $4 \mathrm{~km}$ product. We show overall that for sea ice, trends towards earlier open water $\left(-7.7 \mathrm{~d}_{\text {decade }^{-1}}, \mathrm{p}<0.05\right)$ and later final freeze $\left(10.6 \mathrm{~d}_{\text {decade }}{ }^{-1}, \mathrm{p}<0.05\right)$ are evident. Trends 15 towards earlier first snow-off $\left(-4.9 \mathrm{~d}\right.$ decade $\left.^{-1}, \mathrm{p}<0.05\right)$, combined with trends toward earlier first snow-on $\left(-2.8 \mathrm{~d}\right.$ decade ${ }^{-1} \mathrm{p}$ $<0.05$ ), lead to almost no change in the length of the snow-free season, despite shifting earlier in the year. Sea ice-off, lake ice-off and snow-off parameters were significantly correlated, with stronger correlations during the snow/ice-off season compared to the snow/ice-on season. Regionally, the Bering and Chukchi Seas show the most pronounced response to warming, with the strongest trends identified toward earlier ice-off and later ice-on. This is consistent with earlier snow/lake ice-off and later snow/lake ice-on in west and southwest Alaska. In contrast to this, significant clustering between sea ice, lake ice and snow-on trends in the eastern portion of the North American Arctic show an earlier return of snow and ice. The marked regional variability in snow and ice phenology across the pan-Arctic highlights the complex relationships between snow and ice, and their response to climatic change, and warrants detailed monitoring to understand how different regions of the Arctic are responding to ongoing changes.
\end{abstract}




\section{Introduction}

The cryosphere is the second largest component of the global climate system after the ocean, exerting significant effects on the Earth's energy balance, atmospheric circulation, and heat transport (Lemke et al. 2007; Callaghan et al. 2011; Derksen et al. 2012). The relevance for climate variability and change is based on physical properties, such as high surface reflectivity (albedo) and latent heat associated with phase changes, both of which have a strong impact on the surface energy balance (Lemke et al. 2007). The extent and duration of snow and ice cover have direct feedbacks to the climate system as they strongly influence planetary albedo (Rahmstorf, 2010; Derksen et al. 2012). Seasonal snow and ice cover are also important for Arctic ecosystems as they rely on snow and ice cover for feeding, transportation, and habitat (Dersken et al. 2012). Additionally, the traditional ways of life of many Northern residents depend on snow and ice cover for sources of food, transportation, and economic activities (Derksen et al. 2012). Recent assessments reveal strong linkages between decreasing snow and ice cover and increasing temperatures in the Arctic (e.g. Hernandez-Henriquez et al. 2015; Johannessen et al. 2016; Druckenmiller and Ritcher-Menge, 2020). Reductions in sea ice extent, decreases in snow cover duration, and earlier melt onset in Arctic and sub-Arctic lakes have been reported (Serreze and Stroeve, 2015; Surdu et al. 2016; Mudryk et al. 2018). Arctic surface air temperatures in 2019 were the second highest in the 120-year (1900 - present) observational record (Druckenmiller and Richter-Menge, 2020), and are projected to continue to increase well into the twenty-first century (Overland, 2020). Though the Arctic as a whole is undergoing climatic change, observations are often marked by regional differences tied in part to global connections via the atmosphere and ocean (Druckenmiller and Richter-Menge, 2020). For example, sea ice in the Alaska/Russia region has shown large reductions in sea ice extent over the past decade, which has been linked to strong warming and large sea surface temperature anomalies in this area (Druckenmiller and Richter-Menge, 2020; Perovich et al. 2020). The Canadian Arctic Archipelago (CAA), however, has been shown to exhibit earlier freeze trends during recent years (e.g. Dauginis and Brown, 2020) and weaker trends toward earlier melt onset compared to other Arctic regions (e.g. Mahmud et al. 2016; Marshall et al. 2019). Furthermore, the effect of warming on sea ice dynamics in this region can be counterintuitive as warming could result in increased ice import from the Arctic Ocean into the CAA (Melling, 2002; Howell and Brady, 2019; Moore et al., 2021). Therefore, monitoring Arctic snow and ice cover is critical to improve our understanding of this complex and variable region in the context of climate variability and change.

Monitoring Arctic snow and ice cover largely relies on the use of satellite observations, as ground-based observations are constrained by limited in situ data, large gaps and biases in surface observing networks, and limited geographic coverage (Brown et al. 2010; Brown and Duguay, 2011). Satellite-based microwave data are most commonly used in snow and ice monitoring as they provide information regardless of solar illumination and cloud cover (Brown et al. 2014). Microwave measurements have been used to estimate snow (both on land and on sea ice) and ice melt and freeze onset (e.g. Howell et al. 2006; Yackel et al. 2007; Markus et al. 2009; Wang et al. 2011; Zheng et al. 2017) at various spatial resolutions ranging from 6.25 to $25 \mathrm{~km}$ (Brown et al. 2014). The Special Sensor Microwave/Imager (SSM/I) and Scanning Multichannel Microwave Radiometer (SMMR) passive microwave datasets have been widely used in snow and sea ice mapping (e.g. Cho et al. 2017; 
Lynch et al. 2017; Crawford et al. 2018). Passive microwave data are well-suited for snow and ice monitoring due to allweather imaging capabilities and long available records (since the late 1970s), though the coarse resolution (25 km) limits their application and reduces the accuracy of estimates (Derksen et al. 2004; Gao et al. 2010; De Lannoy et al. 2012). There are well-documented uncertainties in using passive microwave measurements to retrieve snow water equivalent and snow cover extent due to differences in snow and surface cover properties (e.g. snow depth, snow grain size, topography, vegetation), which influence microwave emission and backscatter (Brown et al. 2010; Park et al. 2012; Tedesco et al. 2015). The coarse spatial resolution also limits the ability of the sensors to resolve small leads and polynyas and can result in errors near coastal areas due to pixel-based land contamination (Howell et al. 2006; Brown et al. 2014). Johnson and Eicken (2016) note that strong brightness temperature contrasts across pixels can result in falsely high estimates of sea ice concentration, particularly during the summer when there is open water near coastal areas. SMMR and SSM/I are less commonly used in lake ice applications as the spatial resolution limits analyses to large lakes only. Additionally, the $85 \mathrm{GHz}$ channel is susceptible to considerable atmospheric interference, and the $25 \mathrm{~km}$ spatial resolution can result in large differences in water/land brightness temperatures (Cavalieri et al. 1999; Howell et al. 2009).

Optical remote sensing data have also been used to monitor Arctic snow and ice cover (e.g. Nitze et al. 2017; Young et al. 2018) as they provide an improved spatial resolution (e.g. $500 \mathrm{~m}$ Moderate Resolution Imaging Spectroradiometer Snow Product) compared to passive microwave data. The use of optical imagery is limited to the spring and summer months in highlatitude regions as there is no source of illumination during late fall and winter due to polar darkness. Additionally, the poor temporal resolution of some optical data (e.g. 16 days for Landsat, 8-day MODIS snow product) can introduce uncertainty and inaccuracy into estimates of snow conditions on the Earth's surface. Active microwave data have been used successfully in snow (e.g. Brown et al. 2007), sea ice (e.g. Mortin et al. 2014), and lake ice (e.g. Howell et al. 2009) applications. Active microwave algorithms using synthetic aperture radar (SAR) provide high resolution (20 to $100 \mathrm{~m}$ ) retrieval of snow and ice parameters (e.g. Surdu et al. 2016; Zhu et al. 2018; Howell and Brady, 2019). SAR estimates of snow and ice cover provide the highest spatial resolution compared to other products, however the moderate temporal resolution, narrow swath width, and limited image availability across the Arctic limits the application of SAR to smaller geographic regions (Brown et al. 2014; Howell et al. 2019). Multisensor approaches exploiting advantages of microwave and optical sensors have been used to estimate snow thickness on first year sea ice (e.g. Zheng et al. 2017) and to resolve leads and polynyas at an improved spatial

85 resolution (e.g. Ludwig et al. 2019). The all-weather capabilities of microwave data combined with high temporal resolution of optical imagery can improve estimates of snow and ice parameters in the Arctic.

An alternative approach to snow and ice mapping is the use of the National Ice Center Interactive Multisensor Snow and Ice Mapping System (IMS) product. IMS is created using a variety of multi-sourced datasets (e.g. optical imagery, microwave data, ancillary data) and provides daily maps of snow and ice cover at $24 \mathrm{~km}, 4 \mathrm{~km}$, and $1 \mathrm{~km}$ spatial resolutions

90 (Ramsay 1998; Helfrich et al. 2007). The daily temporal resolution and all-weather monitoring capabilities make IMS suitable in snow cover applications (e.g. Brubaker et al. 2005; Chen et al. 2012; Yu et al. 2017) and lake ice monitoring on large lakes (e.g. Brown and Duguay, 2012; Duguay et al. 2012, 2013, 2014, 2015; Duguay and Brown, 2018). Though not commonly 
used in sea ice applications, Brown et al. (2014) show that IMS is advantageous over several automated algorithms for monitoring sea ice phenology. IMS is also able to improve sea ice estimates by reducing land contamination and better representing coastal regions compared to passive microwave estimates (Brown et al. 2014), and to resolve finer-scale details between narrow ocean channels (Dauginis and Brown, 2020). This work expands on the work of Dauginis and Brown (2020) and examines changes in sea ice, lake ice, and snow phenology from $1997-2019$ across the pan-Arctic. The objectives of this paper are to 1) assess changes in sea ice, lake ice, and snow phenology from 1997 - 2019 across the pan-Arctic and 2) analyze regional changes in snow and ice phenology during more recent years (2004 - 2019) across the pan-Arctic.

\subsection{Methodology}

\subsection{Study regions}

In this study, regions north of $56^{\circ}$ were considered when examining pan-Arctic snow and ice phenology in the first section of the results (Figure 1). For the second section of the results, a regional approach was taken. For snow and lake ice, phenology parameters were considered on a hemispheric scale (i.e. North America and Eurasia). Further regional subdivisions are provided in Table 4 for the snow and lake ice trends. For sea ice, phenology parameters were examined in three broad regions (with some subregions included in Table 4): Canadian Arctic, Alaska/Far East Russia, and Eurasian Arctic. 'Canadian Arctic' includes Baffin Bay, Hudson Bay, and the CAA; 'Alaska/ Far East Russia' includes the Beaufort, Chukchi, and Bering seas; 'Eurasian Arctic' includes the East Siberian, Laptev, Kara, Barents, and Greenland seas. These regions were grouped based on their broadly similar ice-phenology characteristics.

\subsection{Data}

Snow and ice data were obtained from the National Ice Center Interactive Multisensor Snow and Ice Mapping System (IMS) snow and ice product. IMS is an operational product used to map daily snow and ice cover over the Northern Hemisphere at $1 \mathrm{~km} \mathrm{(2014} \mathrm{-} \mathrm{present),} 4 \mathrm{~km} \mathrm{(2004} \mathrm{-} \mathrm{present),} \mathrm{and} 24 \mathrm{~km} \mathrm{(1997} \mathrm{-} \mathrm{present)} \mathrm{spatial} \mathrm{resolutions}$ (https://www.natice.noaa.gov/ims/). Analysts use a variety of multi-sourced datasets (for a complete list of data sources, see

115 National Snow and Ice Data Center, https://nsidc.org/data/g02156) to subjectively produce maps with discrete values assigned to land, snow-covered land, water, and ice. Snow mapping primarily relies on visible imagery; however, if visible imagery is unavailable due to cloud occlusion or low solar illumination, microwave data is used instead (Helfrich et al. 2007; Brown et al. 2010). As misidentification errors associated with microwave data can occur, analysts rely more on snow climatology compared to microwave data to estimate high latitude snow cover during winter months (Chang et al. 1996; Foster et al. 2005; Helfrich et al. 2007; Derksen 2008; Brown et al. 2010). Ice cover analysis primarily relies on AVHRR or MODIS observations, however microwave-based retrievals and ice climatology are used when visible imagery is unavailable, with microwave retrievals representing approximately $30-35 \%$ of the ice cover input (Helfrich et al. 2007). 
Temperature data are from the European Centre for Medium-Range Weather Forecasts (ECMWF) ERA5 global reanalysis and were compared to changes in snow and ice phenology. ERA5 provides coverage of the entire Arctic at a spatial resolution of approximately $31 \mathrm{~km}\left(0.25^{\circ}\right)$. Monthly $2 \mathrm{~m}$ temperature data were used to calculate temperature trends from 2004 -2019 .

\subsection{Methodology}

The $24 \mathrm{~km}$ and $4 \mathrm{~km}$ IMS products were used to examine changes in snow and ice phenology dates across the panArctic following the methodology of Brown et al. (2014) and Dauginis and Brown (2020). For each pixel, consecutive days of IMS imagery were compared to determine the first and last changes between snow/ice and land/water to determine the timing of the snow/ice-on and off parameters examined. The phenology parameters used in this study and their definitions can be found in Table 1. The $24 \mathrm{~km}$ IMS product was used to examine trends in mean snow and sea ice phenology dates across the pan-Arctic from 1997 - 2019. For lake ice, only the $4 \mathrm{~km} \mathrm{IMS} \mathrm{product} \mathrm{(2004-2019)} \mathrm{was} \mathrm{used} \mathrm{since} \mathrm{the} 24 \mathrm{~km}$ product can only detect very large lakes (Figure 2). In addition to detecting more lakes, the $4 \mathrm{~km}$ IMS product can also provide more detailed information on lake ice phenology within each lake, as shown in Figure 2.

To investigate the relationship between phenology parameters and temperature, correlations between variables were examined using Spearman's rank correlation coefficient $(\rho)$ as this method describes the overall strength of the relationship between two variables and does not require data to follow independent normal distributions (non-parametric) (Hauke and Kossowski, 2011). Datasets were detrended prior to correlation analysis to ensure relationships were not a result of a shared trend, but rather driven by actual relationships between variability in phenology parameters and temperature (Pizzolato et al. 2014). Data were detrended using the "pracma" package in R (https://CRAN.R-project.org/package=pracma) which removes the linear trend from a given dataset by computing the least-squares fit of a straight line to the data and subtracting the resulting function from the data (Borchers, 2019). The detrended data were then used to calculate Spearman correlation coefficients between phenology parameters and temperature.

To evaluate spatial trends in snow and ice phenology and temperature, $4 \mathrm{~km}$ IMS phenology dates and $2 \mathrm{~m}$ temperature data were analyzed using the "zhang" method of trend analysis, available in the "zyp" package in R (Bronaugh and Werner 2019). This method of trend analysis was proposed by Zhang et al. (2000) and has been successfully used to represent trends in temperature and precipitation (Zhang et al. 2000) lake ice phenology (Murfitt and Brown 2017) and sea ice and snow phenology (Dauginis and Brown, 2000). The "zhang" method is suitable for analyzing spatial trends in this study as it employs non-parametric tests and accounts for autocorrelation. The linear trend is removed from the time series if it is significant and the autocorrelation computation repeats until the differences in the estimates of the slope and autoregressive model in two consecutive iterations is smaller than 1\% (Bronaugh and Werner 2019). The Mann-Kendall test is applied to the resulting time series and the Sen's slope of the trend is computed (Bronaugh and Werner 2019). The final result is the Sen's slope (amount of increase or decrease) at each location over the given time period, as well as the significance of each trend (Bronaugh and Werner 2019). Interannual and regional variability in snow and ice conditions will inherently affect phenology 
parameters, particularly for sea ice, which may not entirely clear out of some regions in a particular season leading to no iceoff or -on phenology detected for that year (Dauginis and Brown, 2020). Pixels with less than 14 years of phenology data (e.g. regions where ice-off only occurs occasionally) are treated as No Data, meaning the spatial extent of the trend examination represents the geographic region where snow/ice-off has occurred in at least 14 of the last 16 years.

160 Finally, clustering in the trend data was explored using local indicators of spatial association (Anselin, 1995) through ESRI ArcGIS. The statistically significant clusters of high and low values (trend strengths) were mapped to highlight regions where the phenology variables were responding similarly over the study period.

\section{Results and Discussion}

\subsection{Trends and Correlations}

Mean snow, sea ice, and lake ice phenology dates across the pan-Arctic are shown in Figure 3 (4 km IMS, 2004 2019). Sea ice open water dates range from mid-March to late September and snow-off dates range from mid-March to late August (Figure 3a, b). Lake ice-off ranges from late March to late August (Figure 3a, b). Sea ice freeze dates range from midSeptember to late April and snow onset dates range from mid-August to late January (Figure 3c, d). Lake ice-on dates range from early September to early February (Figure 3c, d).

Mean snow, sea ice, and lake ice phenology dates for the $24 \mathrm{~km}(1997$ - 2019) and $4 \mathrm{~km}(2004$ - 2019) IMS products are shown in Figure 4. Overall, the pan-Arctic shows trends toward a longer snow and ice-free season (Figure 4) from 1997 2019, with trends toward earlier snow-off and ice-off and later freeze detected. While the annual variability is similar between the $24 \mathrm{~km}$ and $4 \mathrm{~km}$ mean phenology dates, a small offset of 3.5 days later for ice-off and 3.4 days earlier for ice-on (average) is evident in the sea ice phenology as a result of the resolution differences, mainly attributed to the improved ability of the 4 $\mathrm{km}$ product to resolve smaller-scale features and changes in the ice cover extent than the $24 \mathrm{~km}$ product can detect (e.g. leads, polynyas, near-shore conditions, and changes at the ice edges) (Brown et al. 2014; Dauginis and Brown, 2020). The overall agreement between the products is $<1$ day for the snow phenology dates.

Sea ice open water dates both show significant negative (earlier) trends (Figure 4a), with a larger negative trend

180 detected for first open water (FOW,$-7.72 \mathrm{~d}$ decade $^{-1}, \mathrm{p}<0.05$ ) compared to water clear of ice (WCIs, $-3.31 \mathrm{~d}_{\text {decade }}^{-1}, \mathrm{p}<$ 0.05). Both sea ice-off parameters are most strongly correlated with temperature in September $(\rho=-0.69$ and $-0.60, p<0.05$; Table 2), followed by June ( $\rho=-0.6$ for both, $p<0.05$ ), July $(\rho=-0.58$ and $-0.57, p<0.05$ ), and April $(\rho=-0.50$ and $-0.57, p$ $<0.05$ ). Snow-off dates show similar trends to ice-off parameters, with both first snow-off (first_soff, $-4.90 \mathrm{~d}$ decade ${ }^{-1}, \mathrm{p}<$ 0.05 ) and final snow-off (final_SofF, $-3.21 \mathrm{~d}$ decade $^{-1}, \mathrm{p}>0.05$ ) becoming earlier (Figure $4 \mathrm{~b}$ ), and with first snow-off 185 significantly correlated to temperatures in June and July ( $\rho=-0.46$ and $-0.49, p<0.05$; Table 2$)$. While the first open water 
and first snow-off dates are not significantly correlated, the final snow/ice-off parameters are (sea ice water clear of ice and final snow-off dates, $\rho=0.46$ and $0.64, \mathrm{p}<0.05$, for 24 and $4 \mathrm{~km}$ IMS products respectively) (Table 3).

During the snow/ice-off season, lake ice first open water $\left(\mathrm{FOW}_{\mathrm{L}}\right)$ and water clear of ice $\left(\mathrm{WCI}_{\mathrm{L}}\right)$ dates are significantly correlated with their equivalent snow and sea ice-off parameters from $2004-2019$ (Table 3). Stronger relationships are identified between lake ice and sea ice off parameters ( $\rho_{\text {Fow Sea Ice and Lake Ice }}=0.62$ and $\rho_{\text {WCI Sea Ice and Lake Ice }}=0.72, p<0.05$ ) compared to lake ice and snow ( $\rho$ first snow-off and Fow Lake Ice $=0.55$ and $\rho$ final snow-off and WCI Lake Ice $=0.51, p<0.05$ ). Trends for lake ice first open water and water clear of ice dates from $2004-2019$ are negative $\left(-0.76\right.$ and $-0.02 \mathrm{~d}$ decade $^{-1}, \mathrm{p}>0.05$, though neither are statistically significant. We acknowledge that the 16-year time series (Figure 4c) does not provide a comparative time-span to the other trends examined; however, it should be noted that the direction of the trends are negative (earlier) and therefore follow a similar pattern observed in snow and sea ice trends during the $1997-2019$ melt season.

Sea ice freeze onset (FOs) shows a slightly positive (later) trend $\left(0.36 \mathrm{~d} \mathrm{decade}^{-1}, \mathrm{p}>0.05\right)$, while the continuous ice cover (CICs) trend is much larger and statistically significant $\left(10.60 \mathrm{~d}_{\text {decade }}{ }^{-1} \mathrm{p}<0.05\right)$ (Figure $\left.4 \mathrm{~d}\right)$. Freeze onset shows significant correlations with air temperature in October $(0.48 \mathrm{p}<0.05$, Table 2$)$, while no significant correlations are identified between air temperature and continuous ice cover. Both first and final snow-on (first_son, final_son) trends are negative, indicating that the pan-Arctic is seeing earlier snow onset over the $1997-2019$ study period. First snow-on is becoming earlier by $2.79 \mathrm{~d} \mathrm{decade}^{-1}(\mathrm{p}<0.05)$ while final snow-on is becoming slightly earlier by $0.64 \mathrm{~d} \mathrm{decade}^{-1}(\mathrm{p}>0.05)$ (Figure $\left.4 \mathrm{e}\right)$. Neither snow-on parameter is significantly correlated with monthly air temperature, though the strongest correlation is identified in October at $0.41(\mathrm{p}>0.05$, Table 2). Snow-on dates show small positive correlations with sea ice freeze parameters, though none are statistically significant (Table 3 ). Lake ice freeze onset (FOL) and continuous ice cover ( $\mathrm{CIC}_{\mathrm{L}}$ ) exhibit trends toward later freeze (4.97 and $4.44 \mathrm{~d}$ decade $^{-1}, \mathrm{p}>0.05$; Figure 4f), and although caution should be taken with the short timespan, it should again be noted that lake ice freeze dates show an overall shift toward later freeze. No significant correlations are detected between lake ice/sea ice and lake ice/snow parameters during the freeze season, though similar to the snow/ice-off season, stronger correlations are detected between lake ice and sea ice freeze compared to lake ice-on and snow-on (Table 3).

Overall, snow and ice cover are coming off earlier across the pan-Arctic, while trends during the freeze season vary for sea ice, lake ice, and snow. Earlier sea ice water clear of ice dates contribute to longer open water duration detected across the pan-Arctic (4.85 d decade ${ }^{-1}, \mathrm{p}>0.05$; Figure 5). Non-significant trends are detected in lake ice parameters, with the resulting open water duration in Arctic lakes increasing by $6.86 \mathrm{~d}$ decade $^{-1}$ from $2004-2019$ (p > 0.05) (Figure 5). Almost no trend in snow-free duration is identified $\left(-0.27 \mathrm{~d}\right.$ decade $^{-1}, \mathrm{p}>0.05$; Figure 5), despite first snow-off trending significantly earlier (Figure 4b).

Examining snow and ice cover at the pan-Arctic scale provides important information on how the cryosphere is responding to climate change as a whole, however the large degree of spatial variability warrants further investigation into snow and ice conditions at regional scales. For example, Dauginis and Brown (2020) demonstrate that the CAA is responding differently to warming compared to other regions of the Arctic; their findings show later summer clearing of ice and earlier sea ice freeze and snow onset since 2004, in line with findings from previous studies that showed no significant trends toward 
earlier sea ice melt onset dates in the CAA (e.g. Mahmud et al. 2016; Marshall et al. 2019). Other Arctic regions (e.g. Baffin Bay, Eastern Greenland, Barents Sea, Beaufort Sea, and Chukchi Sea) have shown significantly earlier sea ice melt onset by 2.3 to $6.9 \mathrm{~d} \mathrm{decade}^{-1}$ (e.g. Stroeve et al. 2014). The response of snow cover to changes in climatic and hydrologic regimes also varies regionally, with northern Canada and eastern Siberia experiencing increased snowfall, while Scandinavia and regions around the Greenland ice sheet are experiencing increasing rainfall (Box et al. 2019). Additionally, ice cover duration in Arctic lakes since 2004 shows interannual and regional variability, with lakes in western Russia showing anomalies ranging from 59 days shorter to 57 days longer, while smaller anomalies were identified in Canadian Lakes (Duguay and Brown, 2018). Therefore, the following section will examine regional variability in sea ice, lake ice, and snow phenology from $2004-2019$ using the $4 \mathrm{~km}$ IMS product as the higher spatial resolution (compared to the $24 \mathrm{~km}$ product) allows finer-scale changes in snow and ice cover to be detected.

\subsection{Regional Variability}

\subsubsection{Snow and Ice-off season}

Short-term trends in sea ice, snow, and lake ice phenology from 2004-2019 are presented in Figures 6 (snow/ice-off) and 7 (snow/ice-on) along with maps identifying significant local clustering in the trends. Median values of the spatial trends in Figures 6 and 7 for regions defined in Figure 1 are reported throughout the following section and included in Table 4.

235 Correlations with $2 \mathrm{~m}$ air temperature for the three main sea ice regions and two main snow/lake ice regions (Figure 1) are presented in Table 5. Overall, sea ice, snow, and lake ice show tendencies toward earlier melt, with the exception of 1) Eurasian snow-off parameters, which show little change from 2004-2019 compared to other Arctic regions and 2) sea ice first open water in the Canadian Arctic. The Alaska/ Far East Russia region exhibited the largest trends toward earlier sea ice-off (medianFirst Open Water Sea Ice $=23$ days) and North America showed larger trends toward earlier snow-off and lake ice-off compared to Eurasia (North America: medianFirst snow-off $=8$ days, medianFirst Open Water Lake Ice $=4$ days; Eurasia medianFirst snow-off $=0$ days, medianFirst Open Water Lake Ice $=1$ day).

Overall, sea ice is clearing out of the Canadian Arctic earlier (WCIs median trend $=7$ days), while the first detection of open water (FOWs) shows a later trend, albeit with considerable regional variability. Significant negative correlations between sea ice-off dates and $2 \mathrm{~m}$ temperature are identified in the Canadian Arctic (FOWs June through September: $\rho=-$ $2450.62,-0.55,-0.82$, and -0.70 ; and WCIs May through September: $\rho=-0.61,-0.69,-0.67,-0.77$, and -0.56 , Table 5), indicating that earlier sea ice-off dates here are related to air temperature during the ice-off season. In the CAA, earlier first open water is detected (median $=4$ days), though changes toward earlier water clear of ice are mostly confined to the southern channels, where temperature increases are larger in August and September (Figure 8h, i). Regions of later WCIs are also evident, for example the Eastern Parry Channel (Dauginis and Brown, 2020). The surrounding area (Cornwallis Island, Bathurst Island,

250 and Northern Somerset Island) shows significant clustering between the sea ice and snow trends (no lakes are large enough to be detected at $4 \mathrm{~km}$ resolution in this region) (Figure $6 \mathrm{c}, \mathrm{d}$ ), further highlighting this local region of later ice/snow-off. The 
Baffin Bay / Davis Strait region overall shows a median trend of 1 day earlier, however, the northern portion (Baffin Bay) and southern portion (Davis Strait) show opposite trend directions ( 9 days earlier vs. 24 days later, respectively) (Figure 6a, Table 4). Warming trends are identified over the northern region of Baffin Bay in July and August ranging from 0.01 to $3^{\circ} \mathrm{C}$ (Figure $8 \mathrm{~g}, \mathrm{~h}$ ) where the notable trends toward earlier ice-off are detected (Figure $6 \mathrm{a}, \mathrm{b}$ ). Later first open water trends are evident for Hudson Bay (median $=2$ days), with earlier water clear of ice trends (median $=7$ days). The median temperature increase during July over Hudson Bay is $0.55^{\circ} \mathrm{C}$, though while the majority of the northern and western portions showing warming trends, the eastern and more southern portions show cooling (Figure 8g). These regions of cooling correspond with the region of predominantly later FOWs trends (median $=2$ days). Significant clustering is shown in the ice and snow-off trends along the southern stretches of Hudson Bay and near-onshore regions (Figure $6 c, d$ ).

Earlier trends for snow and lake ice-off parameters are detected across North America (first_SOFF: 8 days, final_soff: 6 days, FOW $\mathrm{L}_{\mathrm{L}}$ and $\mathrm{WCI}_{\mathrm{L}}: 4$ days). First snow-off is significantly correlated with $2 \mathrm{~m}$ temperatures in March, April and May $(\rho=-0.52,-0.54,-0.62, p<0.05)$, while final snow-off is significantly correlated with May only $(\rho=-0.55, p<0.05)$. Lake ice-off parameters are significantly correlated to April, June, and August $2 \mathrm{~m}$ temperatures (FOWL $\rho=-0.52,-0.53,-0.76$ and WCIL $\rho=-0.51,-0.55,-0.76, \mathrm{p}<0.05$, Table 5).

Looking at the western mainland areas of the Canadian Arctic, snow-off trends are predominantly earlier over the 2004-2019 period (median first_Soff = 11 days, median final_soff = 10 days, Table 4). Links between the sea ice trends and the snow/lake ice trends are evident in the region spanning east from Victoria Island into the central mainland Arctic region, where significant local clustering is identified, with more clustering evident during first snow and ice-off events. Lake ice first open water and water clear of ice are both trending earlier here as well (median $=5$ days for both), with larger trends detected in the eastern portions, likely related to strong warming over the region in May and June (Figure 8e, f). Examining Great Slave Lake and Great Bear Lake indicates that trends for water clear of ice are 4 and 8 days (median values) earlier, consistent with negative ice cover duration anomalies (shorter ice cover duration) for 9 of the last 14 years identified by Duguay and Brown (2018). Lake ice-off dates in northern Quebec (bordered by Hudson Bay and Baffin Bay) show later trends, with both ice-off parameters showing median trends of 9 days later, which corresponds to a widespread cooling pattern over northern Quebec in July from 2004-2019 (Figure 8g). North of this region, the two large lakes on Baffin Island, Nettilling Lake and Amadjuak Lake, show trends for first open water are 3 days (median values) earlier for both lakes, though from 2004-2018 these lakes have shown positive ice cover duration anomalies for 7 of the last 14 ice seasons, with most of the longer ice cover duration anomalies observed during the last six seasons (Duguay and Brown, 2018). Lake Hazen, in the far north, indicates trends towards earlier first open water and water clear of ice overall; however, while the eastern portion of the lake shows earlier iceoff trends, the western portion does indicate later ice-off trends (with ice cover remaining latest on the western portion of the lake in several years).

Sea ice in the Alaska/ Far East Russian coastal region shows large trends toward earlier ice-off, with first open water trends indicating 30 days earlier in the Beaufort Sea, 25 days earlier in Chukchi Sea, and 34 days earlier in the Bering Sea (median values, with slightly larger values for WCIs). The Chukchi and Bering Seas have shown larger sea surface temperature 
warming trends in August compared to the Arctic-wide August mean, and September sea ice extent in the Chukchi Sea was well below the 1981 - 2010 median in 2012, 2018, and 2019 (Druckenmiller and Richter-Menge, 2020; Perovich et al. 2020). Significant correlations between sea ice-off dates and temperature are identified in these regions only in September $(\rho=0.54$, $\mathrm{p}<0.05$, Table 5), however warming patterns are present over the Bering/Chukchi Seas for almost all months since 2004 (Figure 8). First snow-off trends across Alaska/Far East Russia (median $=3$ days earlier) are smaller than compared to Canada, though western Alaska shows strong trends toward earlier snow-off. Strong warming over western Alaska from 2004-2019 during April (Figure 8d) may contribute to earlier snowmelt in the region. The median lake ice first open water date shows trends of 18 days earlier in the Alaska/Far East Russia region, though southwestern Alaska shows some of the largest trends toward earlier ice-off (both FOWL and WCIL) across the pan-Arctic (Figure 6a, Table 4). Significant local clustering in this 295 western region shows that the on-land and sea ice parameters are changing similarly. Focusing on the more northern regions of Alaska, first snow-off trends across North Slope Alaska (NSA) are towards earlier dates (median = 8 days), though final snow-off trends are considerably smaller (median $=1$ day). Lake ice-off across NSA is trending later, with both first open water and water clear of ice showing median dates of 3 days later. Arp et al. (2013) found that the Arctic Coastal Plain (northern Alaska) and Beringia (western Alaska) areas experienced the latest ice-out timing from 2007-2012 compared to other lakes 300 across Alaska, as climatology in these regions is influenced by sea-ice conditions along the Arctic Ocean coast. Though longterm trends (1950 - 2011) indicate earlier ice break-up and shorter ice seasons in NSA (Surdu et al. 2014), the trends toward later ice-off in northern Alaska identified in this study from 2004-2019 (Figure 6a) may be reflecting interannual variability and the complex responses of lake ice to changes in temperature, sea ice, and snow cover conditions. Little to no significant clustering between the snow and ice trends are identified in this region, other than some limited near-shore regions.

Trends in sea ice first open water range from 11 to 16 days earlier while water clear of ice ranges from 24 to 34 days earlier across the Eurasian Arctic seas (Table 4). Warming patterns over the Eurasian seas are detected in July and August (with the strongest warming over the Laptev and Barents Seas in both months), though no significant correlations between sea ice first open water dates and temperature were detected in Eurasia. Water clear of ice for the Eurasia Seas is only significantly correlated with April temperatures $(\rho=-0.59, \mathrm{p}<0.05)$ which coincides with strong warming and earlier ice-off for the Barents

310 Sea region (Figure 3, Table 5). The earlier ice-off trends detected in this study across the Eurasian Arctic are consistent with Bliss and Anderson (2018), who report negative (earlier) trends in sea ice melt onset across Eurasia from 1979-2017 of -9.45 $\mathrm{d}$ decade $^{-1}$ (East Siberian), -7.3 d decade ${ }^{-1}$ (Laptev), $-8.19 \mathrm{~d} d e c a d e^{-1}$ (Kara), $-8.47 \mathrm{~d}$ decade $^{-1}$ (Barents), and $-2.37 \mathrm{~d}_{\text {decade }}{ }^{-1}$ (Greenland). Furthermore, earlier ice-off trends in these regions are consistent with large reductions in September sea ice extent in the East Siberian and Laptev Seas from 1979-2016 (Onarheim et al. 2018). Significant local clustering is identified

315 in the sea ice trends near the Laptev and Kara Seas region and the snow/lake ice trends in the northern region of Central Eurasia (Figure 6c, d).

Overall, snow-off across the broad Eurasian region shows no trend, though both first and final snow-off are significantly correlated to air temperature for April, May and July, with the strongest correlations in May (first_SOFF $\rho=-0.60$, $-0.91,-0.68$; final_SOFF $\rho=-0.56,-0.77,-0.56, p<0.05$ ). Only NW Eurasia shows notable trends in the snow-off timing, with 

the regions, with \pm 2 days (median) or less detected across the regions with the exception of Central Eurasia where the ice cover shows trends towards $7\left(\mathrm{FOW}_{\mathrm{L}}\right)$ and 9 days earlier $\left(\mathrm{WCI}_{\mathrm{L}}\right)$. Lake Onega (northwest Russia) shows earlier first open water (median $=5$ days) and both Onega and nearby Lake Ladoga show earlier water clear of ice trends (Onega median $=6$ days, Ladoga median $=9$ days). From $1955-2015$, total ice cover duration in Lake Onega decreased by 50 days, though decreases were mostly attributed to delayed freeze (Filatov et al. 2019). Earlier break-up dates have been detected in 40 lakes across Finland from 1963 - 2014 (Kuusisto, 2015), however our recent short-term trends show that lake ice-off is becoming slightly later (median $=2$ days) in Finnish lakes nearby to Lake Ladoga and Onega. Mean 4 km IMS imagery shows that the average break-up dates range from mid-April to mid-May in this region, though temperature trends are only negative (cooler) in southwestern Finland during April and positive (warmer) over all of Finland during May (Figure 8d, e).

\subsubsection{Snow and Ice-on season}

Sea ice freeze onset in the Canadian Arctic shows trends towards earlier timing (median $=11$ days), while sea ice within the Alaska/ Far East Russia region and Eurasian regions shows delays in freeze (trends of 8 and 7 days later respectively for freeze onset) (Figure 7a, b). On land, the North American Arctic and the Eurasian regions both show trends towards earlier first snowon $\left(\right.$ median $_{\text {North America }}=8$ days and median Eurasia $=9$ days) and final snow-on (median ${ }_{\text {North America }}=3$ days and median $_{\text {Eurasia }}=7$ days), though spatial variability is evident. Unlike the snow/ice-off season where lake ice-off trends were larger over North America compared to Eurasia, overall trends toward later lake ice freeze onset are larger across Eurasia (median $=8$ days) than North America (median = 2 days) (Figure 6c). Local clustering is again evident across the Arctic (Figure 7c, d), however less sea ice/snow clusters are evident in the freeze maps, with the exception of southern Alaska and northern Quebec (Nunavik), particularly for final freeze. A more detailed regional break down follows.

Earlier sea ice freeze and snow-on trends are detected across the Canadian Arctic. Both the first and final sea ice parameters are significantly correlated with $2 \mathrm{~m}$ temperature from September through December, with the strongest correlations identified in November (FOs: $\rho=0.82$ and CICs: $\rho=0.77, p<0.05$ ). Sea ice shows freeze onset trending earlier by 8 days in the CAA, and 10 days in Hudson Bay and Baffin Bay (median values) (Figure 6c). For the North American region overall (Alaska and Canada, Figure 1), first snow-on dates are significantly correlated with August, September (strongest correlation) and October air temperature $(\rho=0.53,0.77,0.53, p<0.05)$ (final snow-on with only October, $\rho=0.63 p<0.05$ ) (Table 5). First snow-on across the western mainland Canada shows earlier trends (median $=5$ days), though delayed snow onset can be identified along north and northwest regions of Canada (south of the Western Arctic Waterway) (Figure 7a, b). Snow-on also shows earlier trends in northern Quebec ( median $_{\text {first snow-on }}=8$ days, median $_{\text {final snow-on }}=16$ days) and corresponds to both earlier lake ice and sea ice freeze onset trends identified in this region. A large cooling pattern can be seen over eastern 350 Canada in October which may contribute to the earlier snow and ice-on dates in this region (Figure 8j). Earlier snow-on dates in the Canadian Arctic are consistent with observed increases in precipitation across all seasons in Canada from 1948 - 2012 (Vincent et al. 2015). Global climate models project increases in Arctic precipitation over the twenty-first century due to 
enhanced local surface evaporation resulting from sea ice loss; however, recent projections show a shift toward a raindominated Arctic, particularly during summer months (Bintanja and Selten, 2014; Bintanja and Andry, 2017). Nettilling Lake shows trends towards earlier freeze onset (median $=3$ days) and continuous ice cover (median $=1$ day), though there is considerable variability in freeze-up as the east shows trends toward earlier freeze and west shows trends toward later freeze. Great Slave Lake, Great Bear Lake, Amadjuak Lake and Lake Hazen all show trends toward later freeze onset, consistent with later ice formation across Arctic Lakes from 2002 - 2015 (Du et al. 2017; Derksen et al. 2019). Increases in mean monthly lake surface temperatures in August have been reported to delay freeze-up by $0.3 \mathrm{~d}$ decade $^{-1}$ on Lake Hazen from $2000-2012$ (Lehnherr et al. 2018), and warming air temperature trends are evident in the August ERA-5 data from $2004-2019$ as well (Figure 8h). Interestingly, from 2004-2019, freeze onset is showing later trends across most of Lake Hazen, while final freeze is showing earlier trends across the entire lake despite the delayed start to the freeze season. September $2 \mathrm{~m}$ temperature trends show slight cooling trends for the pixels covering the lake ranging from $-0.6^{\circ} \mathrm{C}$ to $-1.4^{\circ} \mathrm{C}$ and would correspond to the time of complete freeze over.

Delayed sea ice freeze is identified throughout the Alaska/ Far East Russia region, while there is considerable variability in snow onset and lake ice freeze (Figure 7a, b). Trends towards later freeze (FOs $=6$ days median, CICs $=8$ days) in the Beaufort Sea are consistent with multi-year ice losses and lengthening of the open water season in this region (Galley et al. 2016). The Chukchi and Bering Seas both show trends toward later freeze onset (medianchukchi Sea $=8$ days and medianBering $\mathrm{Sea}=27$ days) and continuous ice cover (medianChukchi Sea $=19$ days and medianBering Sea $=52$ days), with the Bering Sea representing the region with the largest delay in sea ice freeze across the pan-Arctic. During the ice cover season in 2017/2018 the Bering Sea ice extent was lower than any previous winter in the reconstructed or observed record, attributed to warmer sea surface temperatures, delayed freeze, and frequent storms (Thoman et al. 2020). In 2019 the Bering Sea also had extremely low ice cover during the winter and may have acted as a precursor to low summer ice conditions in the Chukchi Sea (Perovich et al. 2020). Sea ice did not completely freeze over in the Chukchi Sea until December 24 in 2019 (approximately a month later than average), with only 2007 and 2016 showing similar freeze patterns since satellite observations began in 1979 (Perovich et al. 2020). Strong warming trends observed over the Bering and Chukchi Seas from October through January $(+1$ $-+6{ }^{\circ} \mathrm{C}$ ) likely contribute to the delayed freeze detected (Figure $8 \mathrm{j}, \mathrm{k}$ ), though no significant correlations between FOs or CICs and $2 \mathrm{~m}$ temperatures from October to January are identified in this region. First snow-on trends for Alaska are becoming earlier (median $=5$ days), while final snow-on is showing smaller changes (median $=1$ day later). The largest trends toward later snow cover are evident in western Alaska, with 3 days later for first snow-on and 22 days later for final snow-on. Wendler et al. (2017) report a 17\% increase in mean snowfall across Alaska from 1946 - 2014, with the largest increases occurring in west and southwest Alaska. More snowfall here may be tied to warming in this region identified during almost all months from 2004 - 2019 (Figure 8), as warmer air is able to sustain more moisture which can thus facilitate increases in precipitation (Thackeray et al. 2019). First snow-on in the NSA region is becoming earlier (median $=21$ days), whereas final snow-on 385 shows no change overall due to the mix of earlier and later trends throughout the region. Lake ice within the NSA region shows trends toward earlier freeze $\left(\mathrm{FO}_{\mathrm{L}}=8\right.$ days and $\mathrm{CIC}_{\mathrm{L}}=9$ days $)$. 
In Eurasia, sea ice freeze onset is becoming later, though the trends in freeze (Figure 7a, b) are smaller in magnitude than the trends for sea ice-off (Figure 6a, b). The later freeze coincides with warming over the region in September and October (Figure 8i, j), and freeze onset is significantly correlated with October $2 \mathrm{~m}$ air temperature $(\rho=0.57, \mathrm{p}<0.05)$ (Table 5), while no significant temperature correlations were identified with complete ice cover. Snow-on shows predominantly earlier trends across all regions of Eurasia ranging from 4 to 13 days (medians) earlier and has strong significant correlations with both October and January air temperatures for first and final snow-on $(\rho=0.85,0.84$ and $\rho=0.81,0.81$ respectively, $p<0.05)$. Lake ice shows similar patterns to snow onset, with earlier freeze detected over the Eurasian regions, with the exception of the Scandinavian/Northern Europe region where freeze onset shows delays of 28 days (median value) and continuous ice cover shows delays of 19 days (median value) later. Large freeze-up anomalies in this region were also identified through previous lake ice research (e.g. Duguay and Brown, 2018), for example the 2017/2018 freeze season showed delayed freeze up by approximately 2 - 5 weeks compared to the 2004 - 2018 mean. Using data from 1890 - 2015, Karetnikov et al. (2017) show that the number of winters with complete freeze over of Lake Ladoga decreased after 1950 and that the ice season has become shorter. Ice cover trends for first open water and complete ice cover are not included for Lake Ladoga in this study as a complete ice cover did not form in several of the examined years. Trends for water clear of ice (full open water) and freeze onset (first detection of ice) are detectable and included in Table 4.

\section{Conclusion}

This paper examined sea ice, snow, and lake ice phenology across the pan-Arctic using the Interactive Multisensor Snow and Ice Mapping System (IMS) snow and ice products. Using IMS, we were able to examine both long-term snow and ice-on/off trends (1997 - 2019) at a $24 \mathrm{~km}$ spatial resolution, as well as more recent short-term trends in snow and ice phenology (2004 - 2019) at an improved resolution of $4 \mathrm{~km}$. Our results show that the Arctic is moving toward a longer snow and ice-free season, with trends toward earlier snow/ice-off and later freeze detected. Sea ice showed the largest trends toward earlier ice-off and later freeze, with FOWs timing becoming earlier by $7.72 \mathrm{~d}$ decade $^{-1}$ and CICs becoming later by $10.60 \mathrm{~d}$ decade $^{-1}$. Lake ice and snow-off parameters are also showing earlier trends, though not as large as those detected for sea ice.

410 Lake ice-off showed significant correlations with snow-off and sea ice-off, while no significant correlations were found between any snow/lake ice/sea ice parameters during the freeze season. This likely reflects the strong influence of surface air temperature on snow and ice off timing, whereas during the freeze season, precipitation plays an important role in determining the timing of snow onset and lake size/volume is an important determinant for freeze timing.

Sea ice in the Canadian Arctic is clearing earlier overall, though regional variability does indicate some regions of later clearing, while during the freeze season, sea ice-on trends are predominantly earlier (11 and 9 days median for first and final ice cover), showing opposite trends compared to other regions across the pan-Arctic. Snow-off and lake ice-off show predominantly earlier trends across North America with some regional exceptions in the east. Snow onset also shows earlier trends across North America, with snow-on trends moving earlier by 4 to 16 days. Lake ice shows a mixed response, with later 
freeze in the west and earlier freeze in the east - reflective of the cooling air temperature trends over the eastern regions. The largest trends toward earlier sea ice-off were detected in the Alaska/Far East Russia region, with trends towards ice clearing a month later. Snow and lake ice-off timing in this region also shows earlier trends, with some of the largest snow and lake ice trends identified in the Western Alaska region. Delays in sea ice freeze were also observed here (trends of 8 and 14 days later for first and final freeze) with much stronger trends in the Bering Sea region. This is consistent with delayed snow onset over land and delayed freeze onset in lakes across most of Alaska. These phenology trends are likely related to strong temperature increases, as trends in $2 \mathrm{~m}$ temperature are positive during most months from 2004-2019 in this region. Sea ice on the Eurasian side of the Arctic is showing larger trends towards earlier ice-off than later ice-on (roughly a month later ice-off, 1-2 weeks later freeze). No trend in first snow-off dates was detected in Eurasia and only a small change toward earlier final snow-off (median = 1 day) was identified; though larger trends toward earlier snow-off were detected in northwest Eurasia compared to the east. Lake ice shows a similar east-west pattern, with Lake Ladoga and Lake Onega showing larger earlier first open water trends compared to northeast Eurasia. Snow onset is also trending earlier over Eurasia, consistent with previous studies that have documented increases in total annual precipitation during cold seasons over the Arctic (Box et al. 2019).

By examining multiple components of the cryosphere together, we can better understand how warming affects snow and ice cover and how these components are interrelated. As the Arctic continues to experience unprecedented change as a response to increasing temperatures, continuous monitoring of changes in snow and ice cover is essential to improve our understanding of climate variability and changes occurring at not only the pan-Arctic scale but at the regional-scale as well.

\section{Acknowledgements}

Funding for this research has come from the National Science and Engineering Research Council (NSERC Discovery Grant to L. Brown), the Queen Elizabeth II Graduate Scholarship in Science and Technology (QEII-GSST), and the Graduate Expansion Fund (GEF) from the University of Toronto Mississauga. We would also like to thank Stephen Howell and Michael

Brady from Environment Canada for their valuable insight and technical support.

\section{Data}

All data sets used in this study are freely available online.

\section{Author Contributions}

Project conceptualization and methodology were designed by AD and LB, with the formal data analysis carried out by AD.

Original draft was prepared by $\mathrm{AD}$, with review and editing from both $\mathrm{AD}$ and $\mathrm{LB}$. 
https://doi.org/10.5194/tc-2021-52

Preprint. Discussion started: 23 February 2021

(c) Author(s) 2021. CC BY 4.0 License.

(c) (i)

\section{Competing Interests}

The authors declare that they have no conflict of interest

\section{References}

Anselin, L.: Local Indicators of Spatial Association-LISA, Geographical Analysis, 27(2), 93-115, doi: 10.1111/j.15384632.1995.tb00338.x, 1995.

Alexeev, V. A., Arp, C. D., Jones, B. M., and Cai, L: Arctic sea ice decline contributes to thinning lake ice trend in northern Alaska, Environ. Res. Lett., 11(7), 074022, doi: 10.1088/1748-9326/11/7/074022, 2016.

Arp, C. D., Jones, B. M., and Grosse, G.: Recent lake ice-out phenology within and among lake districts of Alaska, USA, Limnol. Oceanogr., 58(6), 2013-2028, doi: 10.4319/lo.2013.58.6.2013, 2013.

Bintanja, R. and Selten, F.M.: Future increases in Arctic precipitation linked to local evaporation and sea-ice retreat, Nature, 509, 479-482, doi: 10.1038/nature13259, 2014.

Bintanja, R. and Andry, O.: Towards a rain-dominated Arctic, Nat. Clim. Change, 7, 263-267, doi: 10.1038/nclimate3240, 2017.

Bliss, A. C., and Anderson, M. R.: Arctic sea ice melt onset timing from passive microwave-based and surface air temperaturebased methods, J. Geophys. Res., 123(17), 9063-9080, doi: 10.1029/2018JD028676, 2018.

Box, J. E., Colgan, W. T., Christensen, T. R., Schmidt, N. M., Lund, M., Parmentier, F. J. W., ... and Walsh, J. E.: Key indicators of Arctic climate change: 1971-2017, Environ. Res. Lett., 14(4), 045010, doi:10.1088/1748-9326/aafc1b, 2019.

Brock, B. W.: Shrinking sea ice, increasing snowfall and thinning lake ice: A complex Arctic linkage explained, Environ. Res. Lett., 11(9), 091004., doi:10.1088/1748-9326/11/9/091004, 2016.

465 Borchers, H. W. 2019. Package 'pracma'. Available online: https://cran.r-project.org/web/packages/pracma/pracma.pdf

Bronaugh, D., and Werner, A. 2019. “zyp”. Available at: https://cran.r-project.org/web/packages/zyp/zyp.pdf

Brown, R., Derksen, C., and Wang, L.: Assessment of spring snow cover duration variability over northern Canada from satellite datasets, Remote Sens. Environ., 111(2-3), 367-381, doi:10.1016/j.rse.2006.09.035, 2007.

Brown, R., Derksen, C. and Wang, L.: A multi-data set analysis of variability and change in Arctic spring snow cover extent, 1967-2008, Geophys. Res., 115, D16111, doi: 10.1029/2010JD013975, 2010.

Brown, L.C. and Duguay, C.R.: The fate of lake ice in the North American Arctic, Cryosphere, 5, 869-892, doi: 10.5194/tc-5869-2011, 2011

Brown, L.C., Howell, S.E., Mortin, J. and Derksen, C.: Evaluation of the Interactive Multisensor Snow and Ice Mapping System (IMS) for monitoring sea ice phenology, Remote Sens. Environ., 147, 65-78, doi: https://doi.org/10.1016/j.rse.2014.02.012, 2014.

Bunzel, F., Notz, D., and Pedersen, L. T.: Retrievals of Arctic sea-ice volume and its trend significantly affected by interannual snow variability, Geophys. Res. Lett., 45(21), 11-751, doi: 10.1029/2018GL078867, 2018. 
https://doi.org/10.5194/tc-2021-52

Preprint. Discussion started: 23 February 2021

(c) Author(s) 2021. CC BY 4.0 License.

(c) (i)

Callaghan, T.V., Johansson, M., Brown, R.D., Groisman, P.Y., Labba, N., Radionov, V., ... and Golubev, V.N.: The changing face of Arctic snow cover: a synthesis of observed and projected changes, Ambio, 40, 17-31, doi: 10.1007/s13280-0110212-y, 2011.

Cavalieri, D. J., Parkinson, C. L., Gloersen, P., Comiso, J. C., and Zwally, H. J.: Deriving long-term time series of sea ice cover from satellite passive-microwave multisensor data sets, J. Geophys. Res., 104(C7), 15803-15814, doi: 10.1029/1999JC900081, 1999.

Chang, A.T.C., Foster, J.L. and Hall, D.K.: Effects of forest on the snow parameters derived from microwave measurements during the BOREAS winter field campaign, Hydrol. Process, 10, 1565-1574, doi: 10.1002/(SICI)10991085(199612)10:12<1565::AID-HYP501>3.0.CO;2-5, 1996.

Cho, E., Tuttle, S. E., and Jacobs, J. M.: Evaluating consistency of snow water equivalent retrievals from passive microwave sensors over the north central US: SSM/I vs. SSMIS and AMSR-E vs. AMSR2, Remote Sens., 9(5), 465, doi: 10.3390/rs9050465, 2017.

Copernicus Climate Change Service (C3S) (2017): ERA5: Fifth generation of ECMWF atmospheric reanalyses of the global climate . Copernicus Climate Change Service Climate Data Store (CDS), September 12020.

Crawford, A. D., Horvath, S., Stroeve, J., Balaji, R., and Serreze, M. C.: Modulation of sea ice melt onset and retreat in the Laptev Sea by the timing of snow retreat in the West Siberian Plain, J. Geophys. Res., 123(16), 8691-8707, doi: 10.1029/2018JD028697, 2018.

Dauginis A and Brown LC.: Sea ice and snow phenology in the Canadian Arctic Archipelago from 1997 - 2018, Arctic Sci., https://doi.org/10.1139/AS-2020-0024, 2020.

De Lannoy, G. J., Reichle, R. H., Arsenault, K. R., Houser, P. R., Kumar, S., Verhoest, N. E., and Pauwels, V. R.: Multiscale assimilation of Advanced Microwave Scanning Radiometer-EOS snow water equivalent and Moderate Resolution Imaging Spectroradiometer snow cover fraction observations in northern Colorado, Water Resour. Res., 48(1)., doi: 10.1029/2011WR010588, 2012.

Derksen, C., Brown, R., and Walker, A.: Merging conventional (1915-92) and passive microwave (1978-2002) estimates of snow extent and water equivalent over central North America, J. Hydrometeor, 5(5), 850-861, doi: 10.1175/15257541(2004)005<0850:MCAPME>2.0.CO;2, 2004.

Derksen, C.: The contribution of AMSR-E 18.7 and $10.7 \mathrm{GHz}$ measurements to improved boreal forest snow water equivalent retrievals, Remote Sens. Environ., 112: 2701-2710, doi: https://doi.org/10.1016/j.rse.2008.01.001, 2008.

Derksen, C. and R. Brown.: Snow [in “Arctic Report Card 2012”]. Jeffries, M. O., J. A. Richter-Menge and J. E. Overland. (Eds.). Available online at http://www.arctic.noaa.gov/reportcard, 2012

Derksen, C., Burgess, D., Duguay, C., Howell, S., Mudryk, L., Smith, S., Thackeray, C. and Kirchmeier-Young, M.: Changes in snow, ice, and permafrost across Canada; Chapter 5 in Canada's Changing Climate Report, (ed.) E. Bush and D.S. Lemmen; Government of Canada, Ottawa, Ontario, p.194-260, 2019. 
Druckenmiller, M. L. and J. Richter-Menge.: Overview [in "State of the Climate in 2019"], Bull. Amer. Meteor. Soc., 101(8), S245 - S246, doi: 10.1175/BAMS-D-20-0086.1, 2020.

Du, J., Kimball, J. S., Duguay, C., Kim, Y., and Watts, J. D.: Satellite microwave assessment of Northern Hemisphere lake ice phenology from 2002 to 2015, Cryosphere, 11, 47 - 63, doi: 10.5194/tc-11-47-2017, 2017.

Duguay, C., Brown, L., Kang, K., and Kheyrollah Pour, H.: [The Arctic] Lake Ice [in "State of the Climate 2011], Bull. Amer. Meteor. Soc., 93(7), S138-S140, doi:10.1175/2012BAMSStateoftheClimate.1, 2012.

Duguay, C., L. Brown, Kang K-K., and Kheyrollah Pour, H.: [The Arctic] Lake ice [In "State of the Climate in 2012"], Bull. Amer. Meteor. Soc., 94(8), S124-S126, doi: 10.1175/2013BAMSStateoftheClimate.1, 2013.

Duguay, C., L. Brown, Kang, K.-K., and Kheyrollah Pour, H.: [The Arctic] Lake ice [In "State of the Climate in 2013"], Bull. Amer. Meteor. Soc., 95 (7), doi: 10.1175/2014BAMSStateoftheClimate.1, 2014.

Duguay, C. R., Bernier, M., Gauthier, Y., and Kouraev, A.: Remote sensing of the cryosphere: Remote sensing of lake and river ice: 1st edn. John Wiley \& Sons, Ltd, UK, 2015a.

Duguay, C., L. Brown, Kang, K.-K., and Kheyrollah Pour, H.: [The Arctic] Lake ice [In “State of the Climate in 2014”]. Bull. Amer. Meteor. Soc. 96 (7), S144-S145, doi: 10.1175/2015BAMSStateoftheClimate.1, 2015 b.

Duguay C and Brown L.: Lake Ice [in Arctic Report Card 2018], https://arctic.noaa.gov/Report-Card/Report-Card2018/ArtMID/7878/ArticleID/785/Lake-Ice, 2018.

Filatov, N., Baklagin, V., Efremova, T., Nazarova, L., and Palshin, N.: Climate change impacts on the watersheds of Lakes Onego and Ladoga from remote sensing and in situ data, Inland Waters, 9(2), 130-141, doi: 10.1080/20442041.2018.1533355, 2019.

Foster, J.L., Sun, C., Walker, J.P., Kelly, R., Chang, A., Dong, J. and Powell, H.: Quantifying the uncertainty in passive microwave snow water equivalent observations, Rem. Sens. Environ., 94,187-203, doi:10.1016/j.rse.2004.09.012, 2005.

Galley, R. J., Babb, D., Ogi, M., Else, B. G. T., Geilfus, N. X., Crabeck, O., ... and Rysgaard, S.: Replacement of multiyear sea ice and changes in the open water season duration in the Beaufort Sea since 2004, J. Geophys. Res. Lett., 121(3), 18061823, doi: 10.1002/2015JC011583, 2016.

Gao, S., Li, Z., Chen, Q., Zhou, W., Lin, M., and Yin, X.: Inter-Sensor Calibration between HY-2B and AMSR2 Passive Microwave Data in Land Surface and First Result for Snow Water Equivalent Retrieval, J. Sens., 19(22), 5023, doi: 10.3390/s19225023, 2019.

Hauke, J., and Kossowski, T.: Comparison of values of Pearson's and Spearman's correlation coefficients on the same sets of data, Quaestiones Geographicae, 30(2), 87-93, doi:10.2478/v10117-011-0021-1, 2011.

540 Helfrich, S. R., McNamara, D., Ramsay, B. H., Baldwin, T., and Kasheta, T.: Enhancements to, and forthcoming developments in the Interactive Multisensor Snow and Ice Mapping System (IMS), Hydrol. Process., 21, 1576-1586, doi: 10.1002/hyp.6720, 2007.

Hersbach, H., Bell, B., Berrisford, P., Hirahara, S., Horányi, A., Muñoz-Sabater, J., ... and Simmons, A.: The ERA5 global reanalysis, Q J R Meteorol Soc., 146(730), 1999-2049, doi: 10.1002/qj.3803, 2020. 
https://doi.org/10.5194/tc-2021-52

Preprint. Discussion started: 23 February 2021

(c) Author(s) 2021. CC BY 4.0 License.

(c) (i)

Hernandez-Henriquez, M. A., Déry, S. J., and Derksen, C.: Polar amplification and elevation-dependence in trends of Northern Hemisphere snow cover extent, 1971-2014, Environ. Res. Lett 10: 044010, doi: 10.1088/1748-9326/10/4/044010, 2015.

Howell, S. E., Tivy, A., Yackel, J. J., and Scharien, R. K.: Application of a SeaWinds/QuikSCAT sea ice melt algorithm for assessing melt dynamics in the Canadian Arctic Archipelago, J. Geophys. Res., 111, C07025, doi:10.1029/2005JC003193, 2006.

Howell, S.E., Duguay, C.R. and Markus, T.: Sea ice conditions and melt season duration variability within the Canadian Arctic Archipelago: 1979-2008, Geophys. Res. Lett., 36, L10502. doi:10.1029/2009GL037681, 2009.

Howell, S.E. and Brady, M.: The dynamic response of sea ice to warming in the Canadian Arctic Archipelago, Geophys. Res. Lett., 46, 13119-13125, doi: 10.1029/2019GL085116, 2019.

Johannessen, O.M., Kuzmina, S.I., Bobylev, L.P. and Miles, M.W.: Surface air temperature variability and trends in the Arctic: new amplification assessment and regionalisation, Tellus A, 68, 28234, doi: 10.3402/tellusa.v68.28234, 2016.

Johnson, M., and Eicken, H.: Estimating Arctic sea-ice freeze-up and break-up from the satellite record: A comparison of different approaches in the Chukchi and Beaufort Seas, Elem Sci Anth., 4, doi: 10.12952/journal.elementa.000124, 2016.

Karetnikov, S., Leppäranta, M., and Montonen, A.: A time series of over 100 years of ice seasons on Lake Ladoga, J. Great Lakes Res., 43(6), 979-988, doi: 10.1016/j.jglr.2017.08.010, 2017.

Kononova, N. K.: The influence of atmospheric circulation on the formation of snow cover on the north eastern Siberia. Ice and Snow, 1, 38-53 (In Russian, English summary), doi: 0.15356/2076-6734-2012-1-38-53, 2012.

Kuusisto, E.: Trends of breakup dates in Finnish lakes in 1963-2014. In 20th International Northern Research Basins Symposium and Workshop Kuusamo, Finland-August 16-21, 2015 (p. 35), 2015.

Lehnherr, I., Louis, V.L.S., Sharp, M., Gardner, A.S., Smol, J.P., Schiff, S.L., Muir, D.C., Mortimer, C.A., Michelutti, N., Tarnocai, C. and Pierre, K.A.S.: The world's largest High Arctic lake responds rapidly to climate warming, Nat. Commun., 9, 1290, doi: 10.1038/s41467-018-03685-z, 2018.

Lemke, P., Ren, J., Alley, R.B., Allison, I., Carrasco, J., Flato, G., ... and Zhang, T.: Observations: changes in snow, ice and frozen ground. In: Climate Change 2007: The Physical Science Basis. Contribution of Working Group I to the Fourth Assessment Report of the Intergovernmental Panel on Climate Change. Solomon, S., D. Qin, M. Manning, Z. Chen, M. Marquis, K.B. Averyt, M. Tignor and H.L. Miller (Eds.). Cambridge University Press, Cambridge, United Kingdom and New York, NY, USA, 2007.

Ludwig, V., Spreen, G., Haas, C., Istomina, L., Kauker, F., and Murashkin, D.: The 2018 North Greenland polynya observed by a newly introduced merged optical and passive microwave sea-ice concentration dataset, Cryosphere, 13(7), doi: 10.5194/tc-13-2051-2019, 2019.

575 Lynch, A. H., Serreze, M. C., Cassano, E. N., Crawford, A. D., and Stroeve, J.: Linkages between Arctic summer circulation regimes and regional sea ice anomalies, J. Geophys. Res., 121(13), 7868-7880, doi: 10.1002/2016JD025164, 2016. 
https://doi.org/10.5194/tc-2021-52

Preprint. Discussion started: 23 February 2021

(c) Author(s) 2021. CC BY 4.0 License.

(c) (i)

Mahmud, M. S., Howell, S. E., Geldsetzer, T., and Yackel, J.: Detection of melt onset over the northern Canadian Arctic Archipelago sea ice from RADARSAT, 1997-2014., Remote Sens. Environ., 178, 59-69, doi: https://doi.org/10.1016/j.rse.2016.03.003, 2016.

Markus, T., Stroeve, J. C., and Miller, J.: Recent changes in Arctic sea ice melt onset, freezeup, and melt season length, J. Geophys. Res., 114, C12024. doi:10.1029/2009JC005436, 2009.

Marshall, S., Scott, K. A., and Scharien, R. K.: Passive Microwave Melt Onset Retrieval Based on a Variable Threshold: Assessment in the Canadian Arctic Archipelago, Remote Sens., 11, 1304, doi: 10.3390/rs11111304, 2019.

Melling, H., Sea ice of the northern Canadian Arctic Archipelago, J. Geophys. Res., 107(C11), 2-1, doi: 10.1029/2001JC001102, 2002.

Moore, G.W.K., Howell, S.E.L., Brady, M. et al.: Anomalous collapses of Nares Strait ice arches leads to enhanced export of Arctic sea ice, Nat Commun 12, 1, https://doi.org/10.1038/s41467-020-20314-w, 2021.

Mortin, J., Howell, S. E., Wang, L., Derksen, C., Svensson, G., Graversen, R. G., and Schrøder, T. M.: Extending the QuikSCAT record of seasonal melt-freeze transitions over Arctic sea ice using ASCAT, Remote Sens. Environ., 141, 214230, doi: 10.1016/j.rse.2013.11.004, 2014.

Mortin, J., Svensson, G., Graversen, R. G., Kapsch, M. L., Stroeve, J. C., and Boisvert, L. N.: Melt onset over Arctic sea ice controlled by atmospheric moisture transport, Geophys. Res. Lett., 43(12), 6636-6642, doi: 10.1002/2016GL069330, 2016.

Mudryk, L.R., Derksen, C., Howell, S., Laliberté, F., Thackeray, C., Sospedra-Alfonso, R., Vionnet, V., Kushner, P.J. and Brown, R.: Canadian snow and sea ice: historical trends and projections, Cryosphere, 12, 1157-1176, doi: 10.5194/tc-121157-2018, 2018.

Nitze, I., Grosse, G., Jones, B. M., Arp, C. D., Ulrich, M., Fedorov, A., and Veremeeva, A.: Landsat-based trend analysis of lake dynamics across northern permafrost regions, Remote Sens, 9(7), 640, doi:10.3390/rs9070640, 2017.

Onarheim, I. H., Eldevik, T., Smedsrud, L. H., and Stroeve, J. C.: Seasonal and regional manifestation of Arctic sea ice loss, J. Clim., 31(12), 4917-4932, doi: 10.1175/JCLI-D-17-0427.1, 2018.

600

Overland, J. E.: Less climatic resilience in the arctic. Weather. Clim. Extremes, 100275, doi: 10.1016/j.wace.2020.100275, 2020.

Park, H., Yabuki, H., and Ohata, T.: Analysis of satellite and model datasets for variability and trends in Arctic snow extent and depth, 1948-2006, Polar Sci., 6(1), 23-37, doi: 10.1016/j.polar.2011.11.002, 2012.

Perovich, D., Meier, W., Tschudi, M., Wood, K., Farrell, S., Hendricks, S., ... and Webster, M.: Sea ice [in "State of the Climate in 2019”]. Bull. Amer. Meteor. Soc. 101(8), S251 - S256, doi: 10.1175/BAMS-D-20-0086.1, 2020.

Pizzolato, L., Howell, S. E., Derksen, C., Dawson, J., and Copland, L.: Changing sea ice conditions and marine transportation activity in Canadian Arctic waters between 1990 and 2012, Clim. Change, 123(2), 161-173, doi: 10.1007/s10584-0131038-3, 2014.

Przybylak, R., and Wyszyński, P.: Air temperature changes in the Arctic in the period 1951-2015 in the light of observational and reanalysis data, Theor. Appl. Climatol., 139(1-2), 75-94, doi: 10.1007/s00704-019-02952-3, 2020. 
Rahmstorf, S.: A new view on sea level rise, Nat. Clim. Change, 4(4), 44-45, doi: 10.1038/climate.2010.29, 2010.

Ramsay, B. H.: The interactive multisensor snow and ice mapping system, Hydrol. Process, 12, 1537-1546, doi: 10.1002/(SICI)1099-1085(199808/09)12:10/11<1537::AID-HYP679>3.0.CO;2-A, 1998.

Serreze, M. C., and Stroeve, J.: Arctic sea ice trends, variability and implications for seasonal ice forecasting, Philos. Trans. R. Soc. A., 373(2045), 20140159, doi: 10.1098/rsta.2014.0159, 2015.

Stroeve, J. C., Markus, T., Boisvert, L., Miller, J., and Barrett, A.: Changes in Arctic melt season and implications for sea ice loss, Geophys. Res. Lett. 41, 1216-1225, doi: 10.1002/2013GL058951, 2014.

Surdu, C. M., Duguay, C. R., Brown, L. C., and Fernández Prieto, D.: Response of ice cover on shallow lakes of the North Slope of Alaska to contemporary climate conditions (1950-2011): radar remote-sensing and numerical modeling data analysis, Cryosphere, 8(1), 167-180, doi: 10.5194/tc-8-167-2014, 2014.

Surdu, C. M., Duguay, C. R., and Fernández Prieto, D.: Evidence of recent changes in the ice regime of lakes in the Canadian High Arctic from spaceborne satellite observations, Cryosphere, 10(3), 941-960, doi: 10.5194/tc-10-941-2016, 2016.

Tedesco, M., Derksen, C., Deems, J.S., and Foster, J. L: Remote sensing of the cryosphere: Remote sensing of snow depth and snow water equivalent: 1st edn. John Wiley \& Sons, Ltd, UK, doi: 10.1002/9781118368909.ch5, 2015.

Thoman, R., Bhatt, U., Bieniek, P., Brettschneider, B., Brubaker, M., Danielson, S., ... and Walsh, J.: The record low Bering Sea ice extent in 2018 [in "Context, impacts, and an assessment of the role of anthropogenic climate change in Explaining extreme events of 2018 from a climate perspective"]. Bull. Amer. Meteor. Soc. 101(1), 53 - 59, doi: 10.1175/BAMS-D19-0175.1, 2020

Thackeray, C. W., Derksen, C., Fletcher, C. G., and Hall, A.: Snow and climate: Feedbacks, drivers, and indices of change, Curr. Clim. Change Rep., 5(4), 322-333, doi: 10.1007/s40641-019-00143-w, 2019.

Vincent, L.A., Zhang, X., Brown, R.D., Feng, Y., Mekis, E., Milewska, E.J., Wan, H. and Wang, X.L.: Observed trends in Canada's climate and influence of low-frequency variability modes, J. Clim., 28, 4545-4560. doi: https://doi.org/10.1175/JCLI-D-14-00697.1, 2015.

Wang, L., Wolken, G.J., Sharp, M.J., Howell, S.E.L., Derksen, C., Brown, R.D., Markus, T. and Cole, J.: Integrated pan-Arctic melt onset detection from satellite active and passive microwave measurements, 2000-2009, J. Geophys. Res., 116, D22103, doi:10.1029/2011JD016256, 2011.

Wendler, G., Gordon, T., and Stuefer, M.: On the precipitation and precipitation change in Alaska, Atmosphere, 8(12), 253, doi: 10.3390/atmos8120253, 2017.

Yackel, J.J., Barber, D.G., Papakyriakou, T.N., and Breneman, C.: First-year sea ice spring melt transitions in the Canadian Arctic Archipelago from time-series synthetic aperture radar data, 1992-2002, Hydrol. Process., 21, 253-265, DOI, 2007.

Young, K.L., Brown, L. and Labine, C.: Snow cover variability at Polar Bear Pass, Nunavut, Arct. Sci., 4, 669-690. doi: dx.doi.org/10.1139/as-2017-0016, 2018. 
https://doi.org/10.5194/tc-2021-52

Preprint. Discussion started: 23 February 2021

(C) Author(s) 2021. CC BY 4.0 License.

(c) (1)

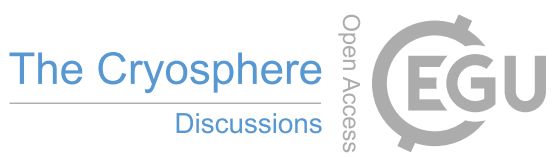

Zhang, X., Flato, G., Kirchmeier-Young, M., Vincent, L., Wan, H., Wang, X., ... and Kharin, V.V.: Changes in Temperature and Precipitation Across Canada; Chapter 4. In Bush, E. and Lemmen, D.S. (Eds.) Canada's Changing Climate Report (pp. 112 - 193). Government of Canada, Ottawa, Ontario, 2019.

Zheng, J., Geldsetzer, T., and Yackel, J.: Snow thickness estimation on first-year sea ice using microwave and optical remote sensing with melt modelling, Remote Sens. Environ., 199, 321-332, doi: 10.1016/j.rse.2017.06.038, 2017.

Zhu, J., Tan, S., King, J., Derksen, C., Lemmetyinen, J., and Tsang, L.: Forward and inverse radar modeling of terrestrial snow using SnowSAR data, IEEE Geosci. Remote Sens., 56(12), 7122-7132, doi: 10.1109/TGRS.2018.2848642, 2018. 


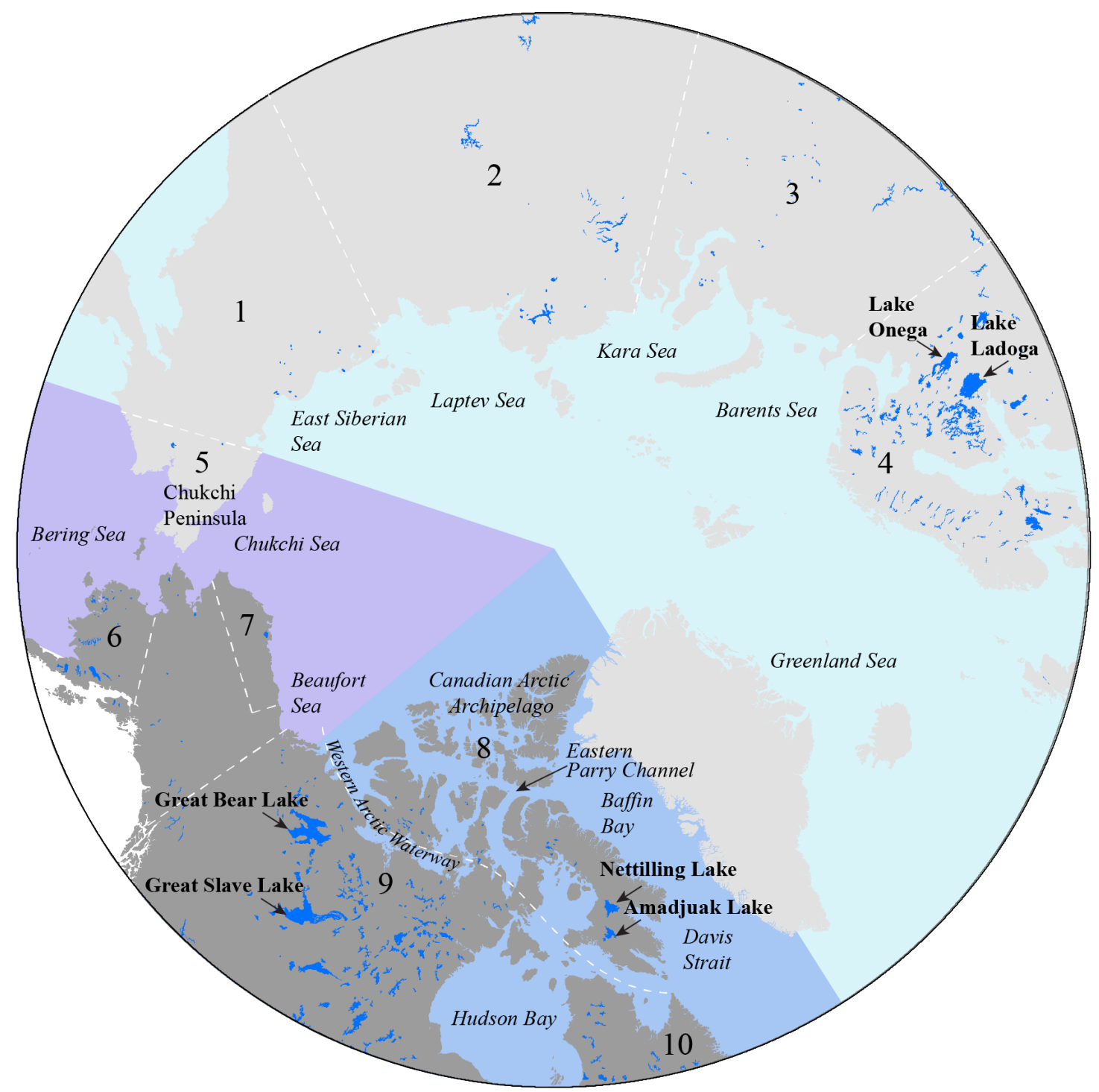

\section{Sea Ice Regions}

Eurasia

Alaska / Far East Russia

Canadian Arctic

\section{Snow and Lake Ice Regions}

\section{Lakes}

Eurasia

1 Eastern Eurasia

2 Central Eurasia

3 Eastern Eurasia

4 Scandinavia / Northern Europe

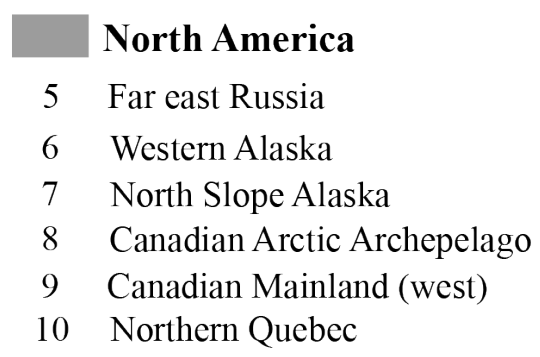

Figure 1. Map of the study area, including the main Sea Ice, Snow and Lake Ice regions (coloured), and subregions (numbered) included in Table 4. 
https://doi.org/10.5194/tc-2021-52

Preprint. Discussion started: 23 February 2021

(c) Author(s) 2021. CC BY 4.0 License.

655
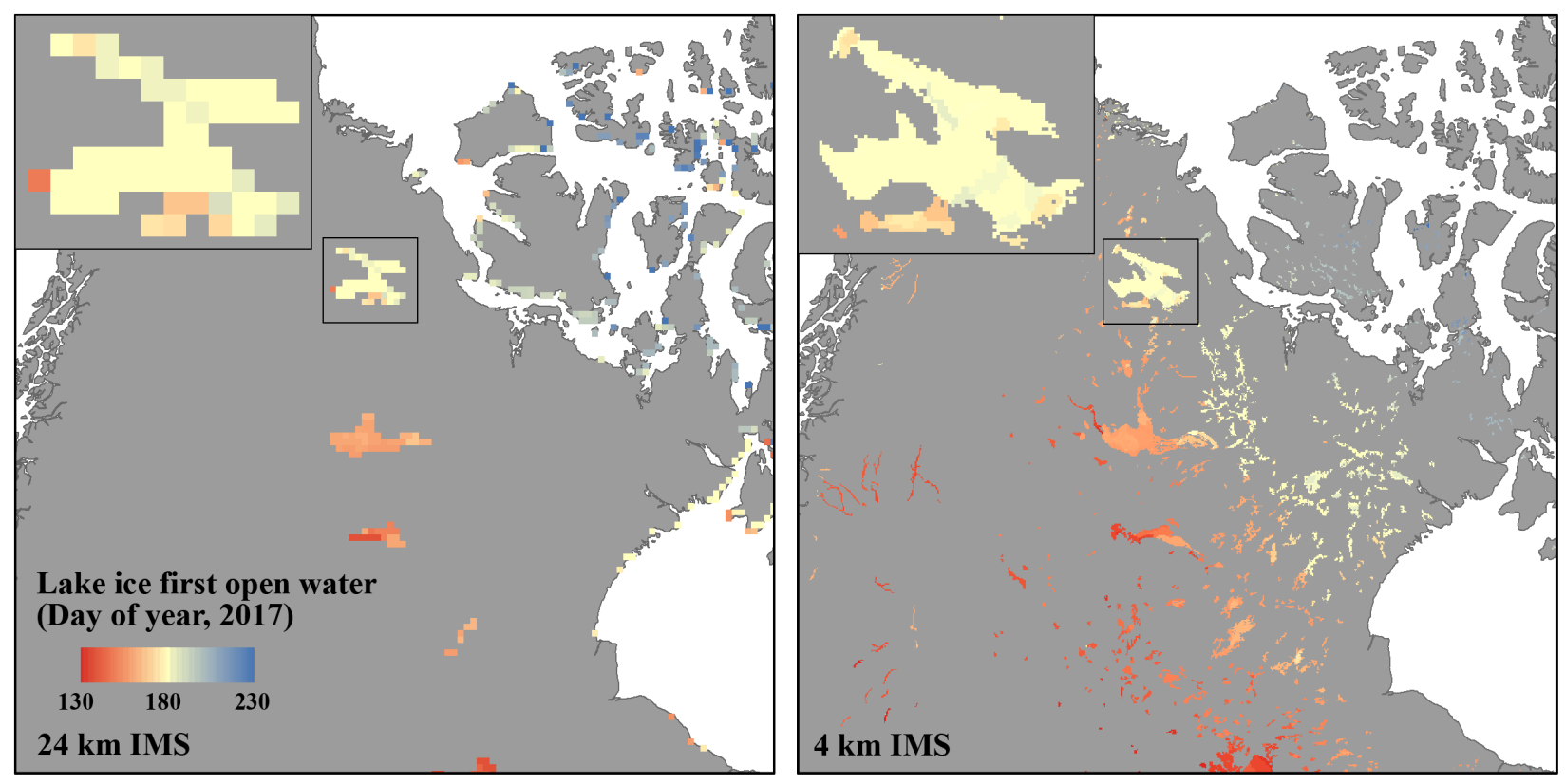

Figure 2. Comparison of $24 \mathrm{~km}$ (left) and $4 \mathrm{~km}$ (right) lake ice first open water in 2017. 
a)

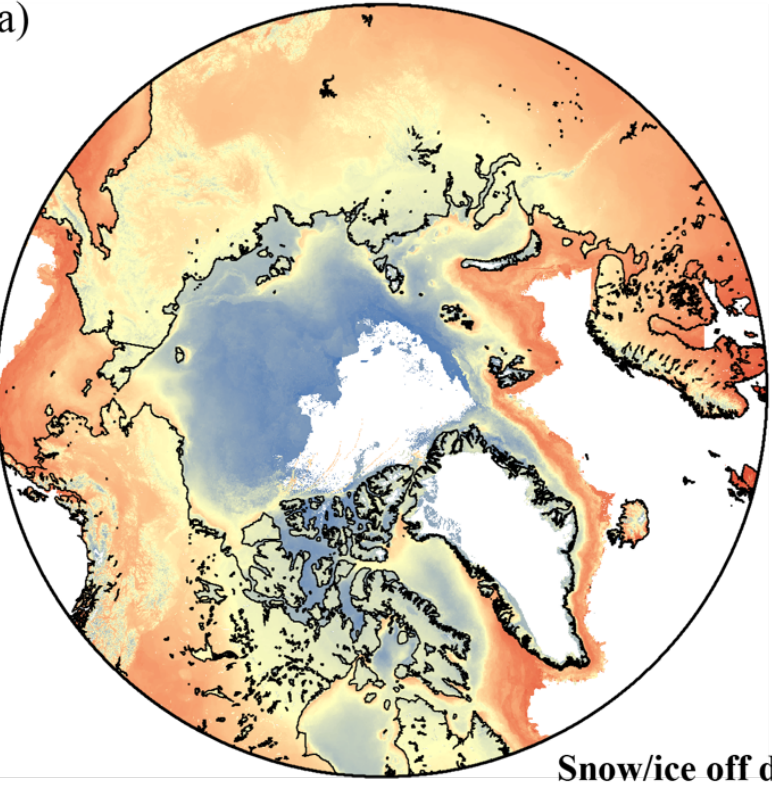

40

c)

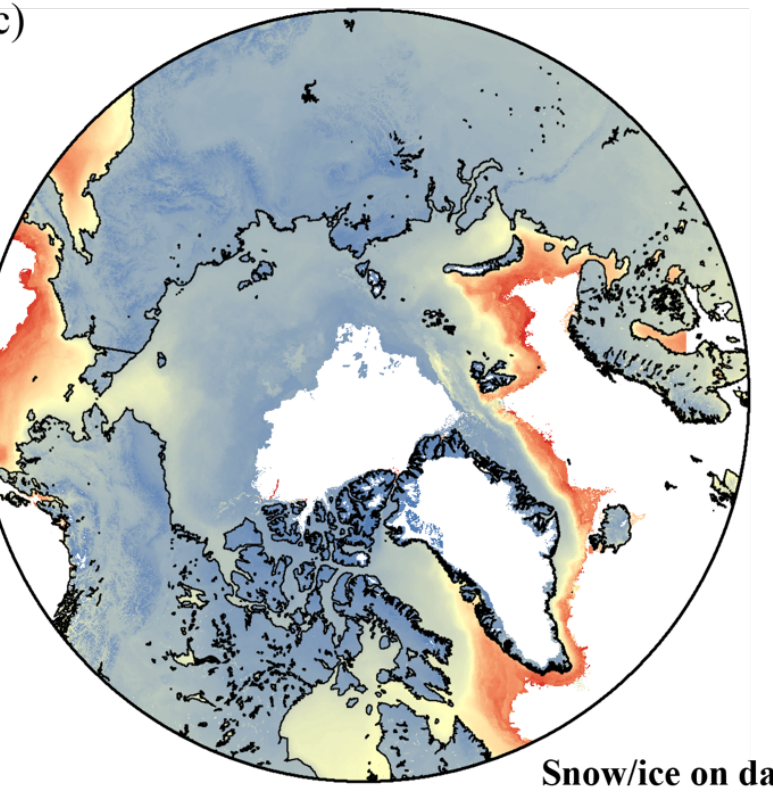

b)

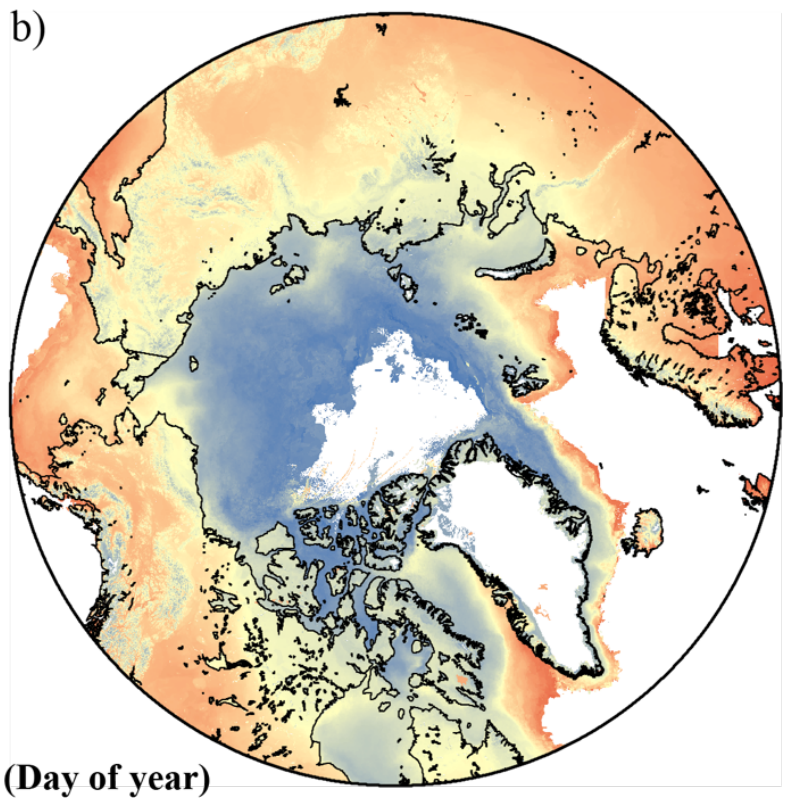

d)

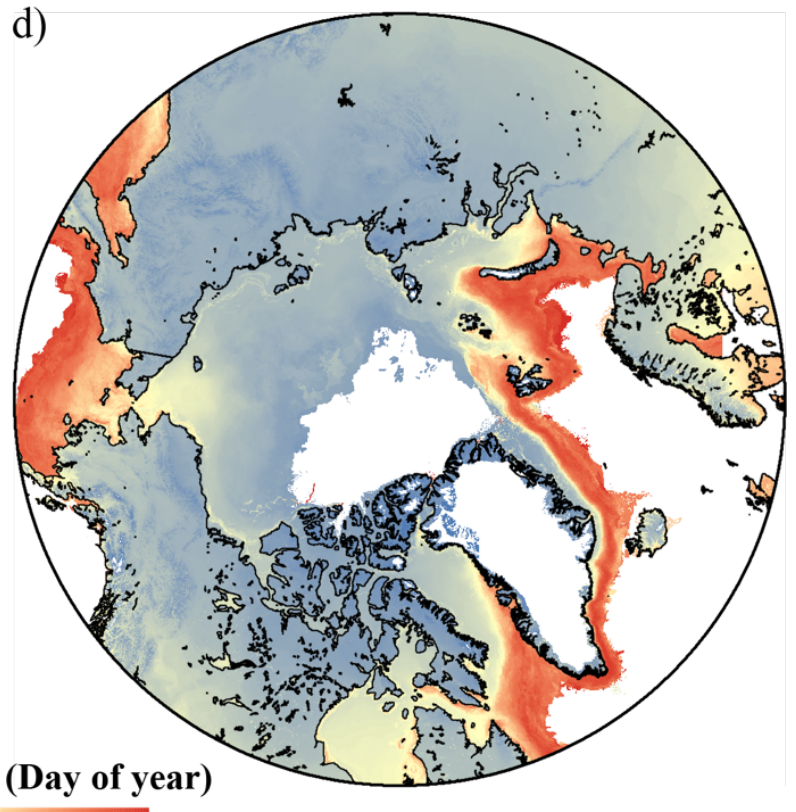

120

Figure 3. Mean 4 km IMS (2004 - 2019) sea ice first open water $\left(F O W_{s}\right)$, first snow-off (first_sofF), and lake ice first open water $\left(F O W_{L}\right)(a)$, sea ice water clear of ice (WCIS), final snow-off (final_sofF), and lake ice water clear of ice $\left(W_{C} I_{L}\right)(b)$, sea ice freeze onset $\left(\mathrm{FO}_{\mathrm{S}}\right)$, first snow-on (first_sov), and lake ice freeze onset $\left(\mathrm{FO}_{\mathrm{L}}\right)(\mathrm{c})$, and sea ice continuous ice cover $(\mathrm{CIC})$, final snow-on (final_son), and lake ice continuous ice cover $\left(\mathrm{CIC}_{\mathrm{L}}\right)(\mathrm{d})$. 


\section{Snow / Ice-off Season}

a)

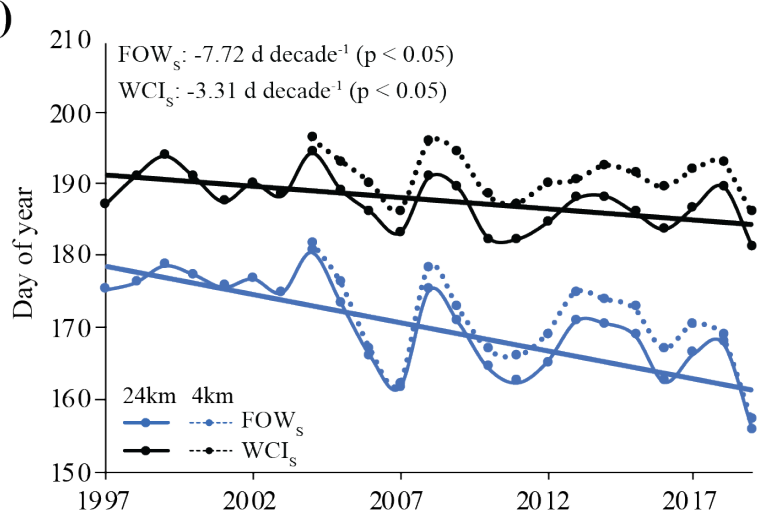

b)

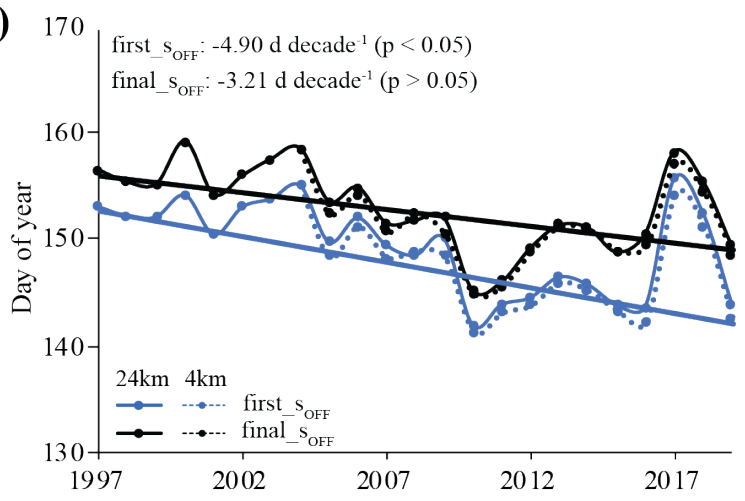

c)

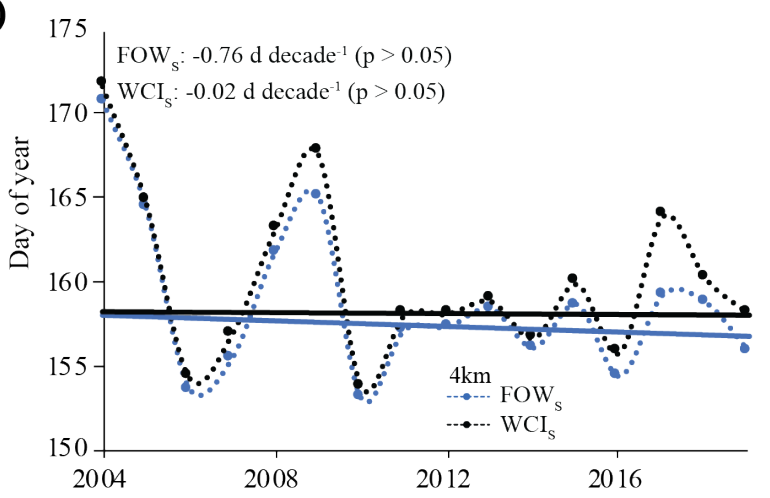

\section{Snow / Ice-on Season}
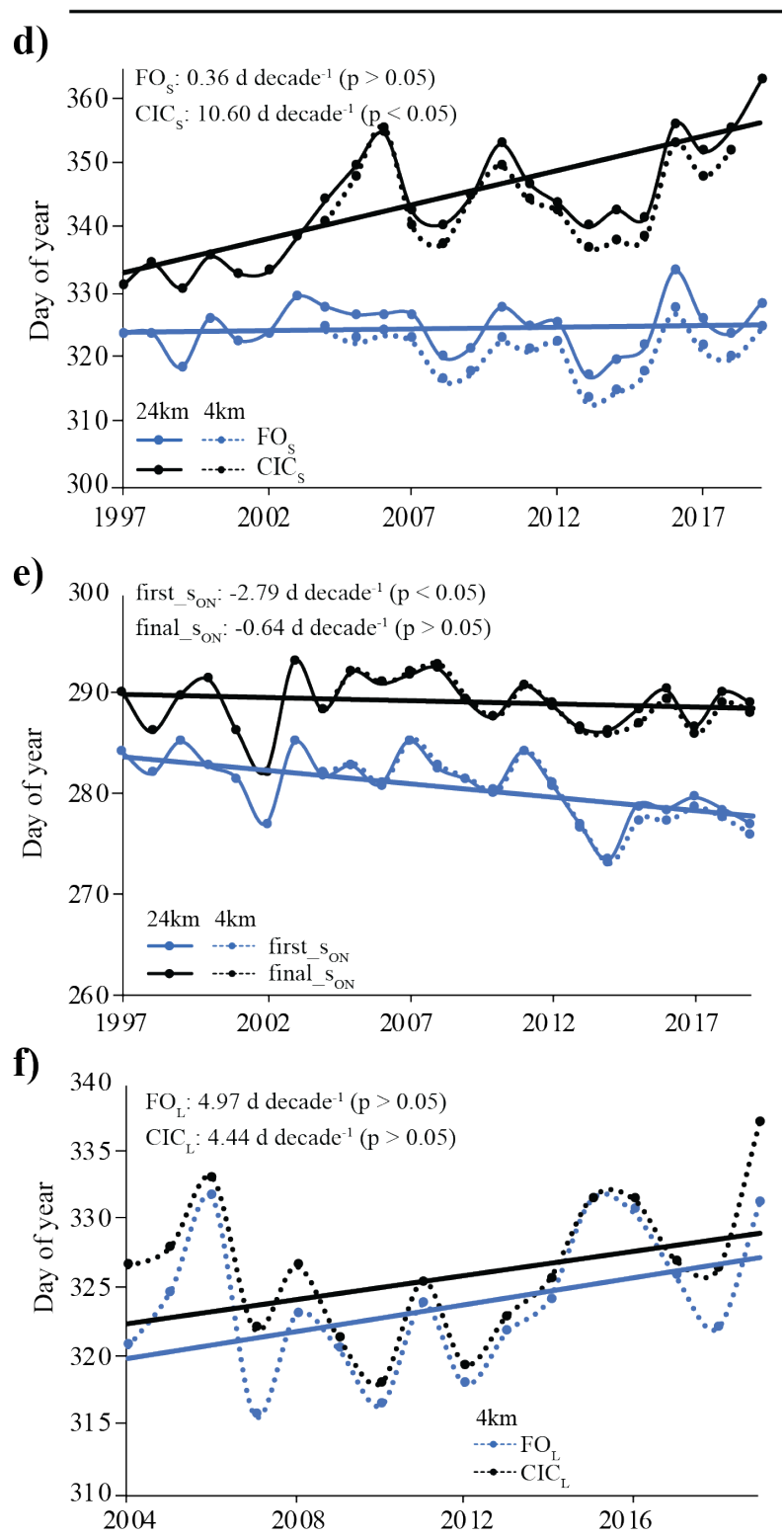

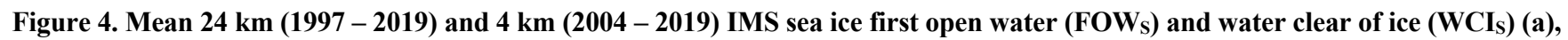
first snow-off (first_soFF) and final snow-off (final_soFF) (b), lake ice first open water (FOW L $_{L}$ ) and water clear of ice (WCI (W) $_{\text {(c) }}$, sea ice freeze onset $\left(\mathbf{F} \bar{O}_{S}\right)$ and continuous ice cover $\left(\bar{C}_{\mathbf{C}} C_{S}\right)(\mathrm{d})$, first snow-on (first_son) and final snow-on (final_son) (e), and lake ice freeze onset $\left(\mathrm{FO}_{\mathrm{L}}\right)$ and continuous ice cover $\left(\mathrm{CIC}_{\mathrm{L}}\right)(\mathrm{f})$. Sen's slope and significance are indicated for each phenology parameter using the $24 \mathrm{~km}$ IMS product. Note that for lake ice, only the $4 \mathrm{~km}$ IMS product was used in this study. 
https://doi.org/10.5194/tc-2021-52

Preprint. Discussion started: 23 February 2021

(C) Author(s) 2021. CC BY 4.0 License.

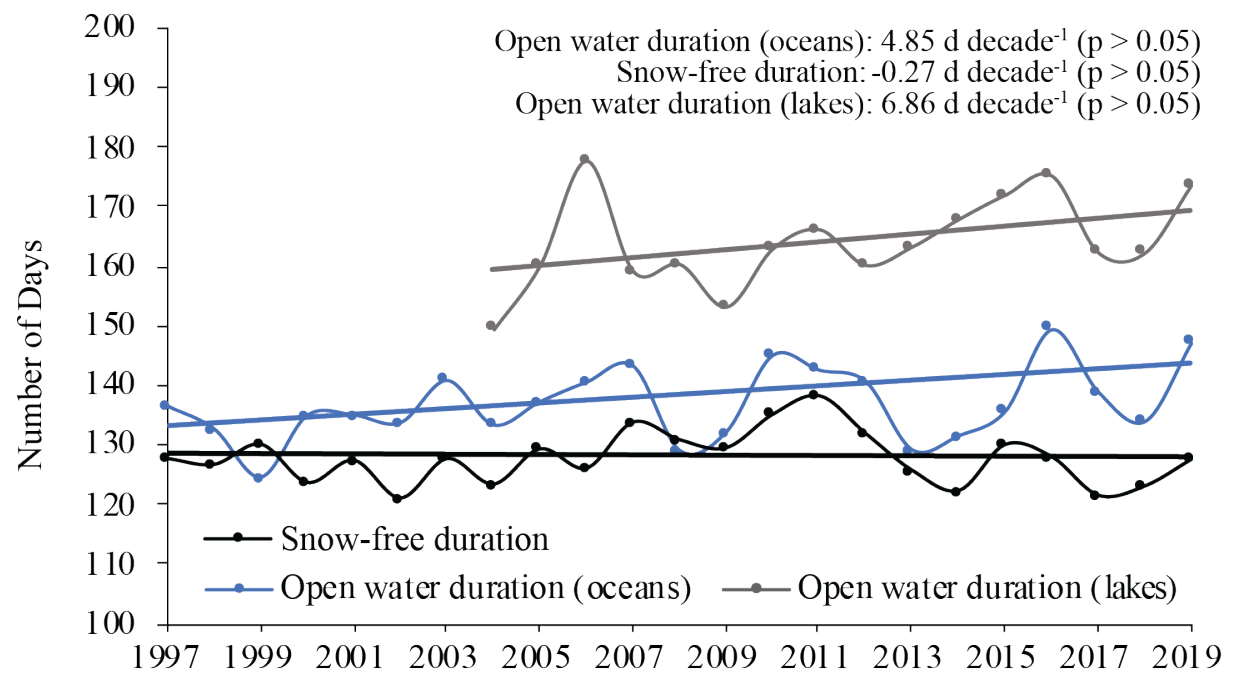

Figure 5. Pan-Arctic open water duration for oceans (1997 - 2019), snow-free duration (1997 - 2019) over land, and open water duration for lakes $(2004-2019)$. Sen's slope of the trend and significance are shown. 


\section{Snow / Ice-off Season}
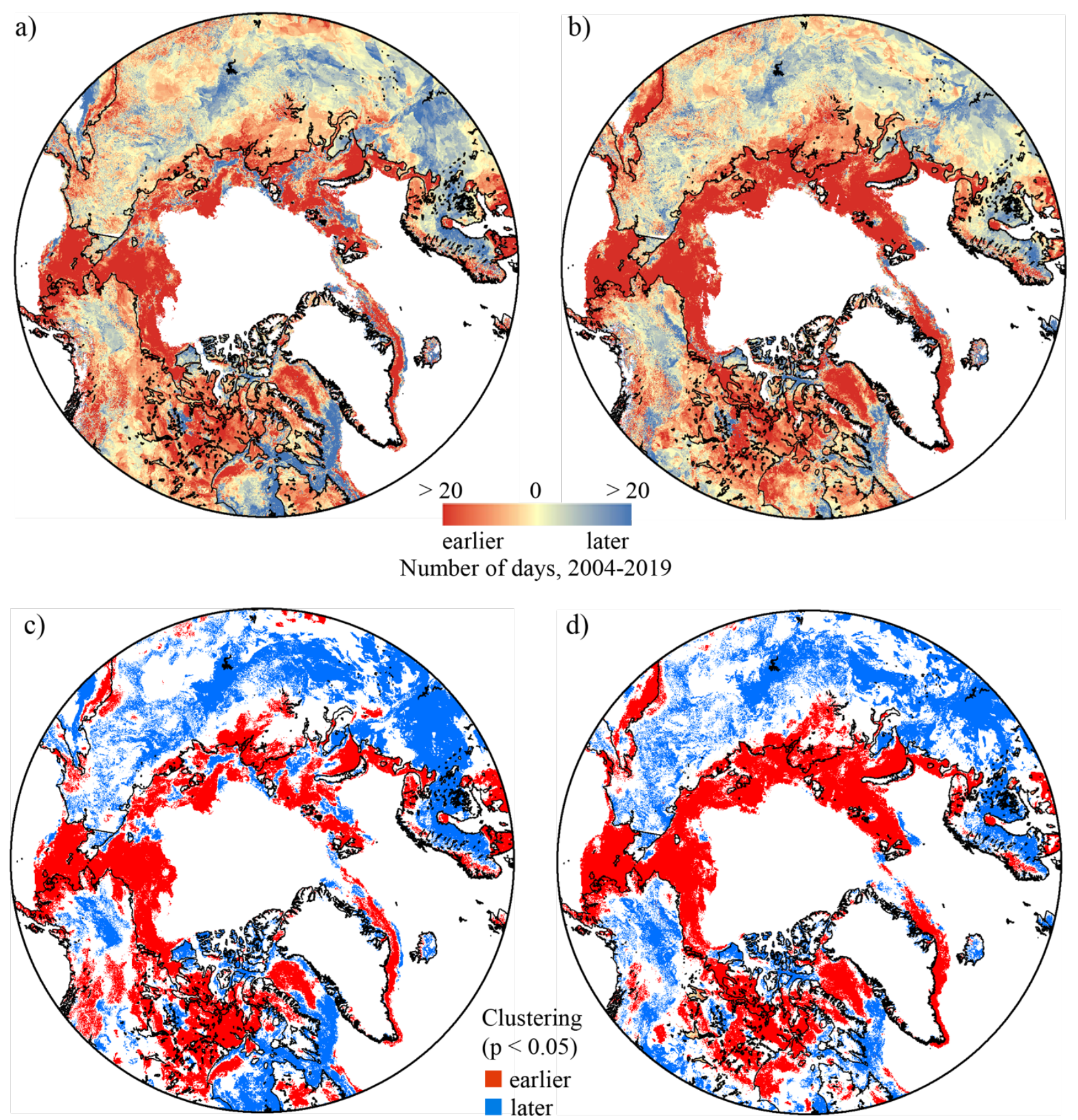

Figure 6. Trends in $4 \mathrm{~km}$ IMS (2004 - 2019) sea ice first open water (FOW $)$, first snow-off (first_sofF), and lake ice first open water $\left(F_{L}\right)(a)$, sea ice water clear of ice (WCI $)$, final snow-off (final_sofF), and lake ice water clear of ice (WCI $\left.\mathbf{L}_{L}\right)(\mathrm{b})$, significant trend clusters in FOWs, FOW $_{L}$ and first_S $S_{O F F}(c)$, and significant trend clusters in $W_{C I}$, WCI $I_{L}$, and final_S $S_{O F F}(d)$. 


\section{Snow / Ice-on Season}

a)

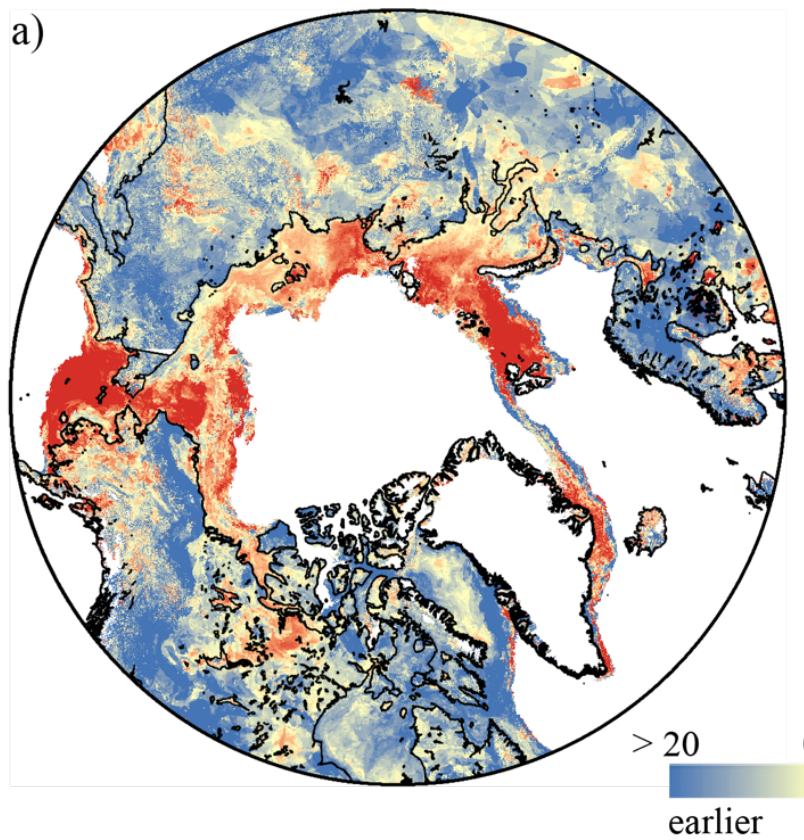

Number later

b)

0

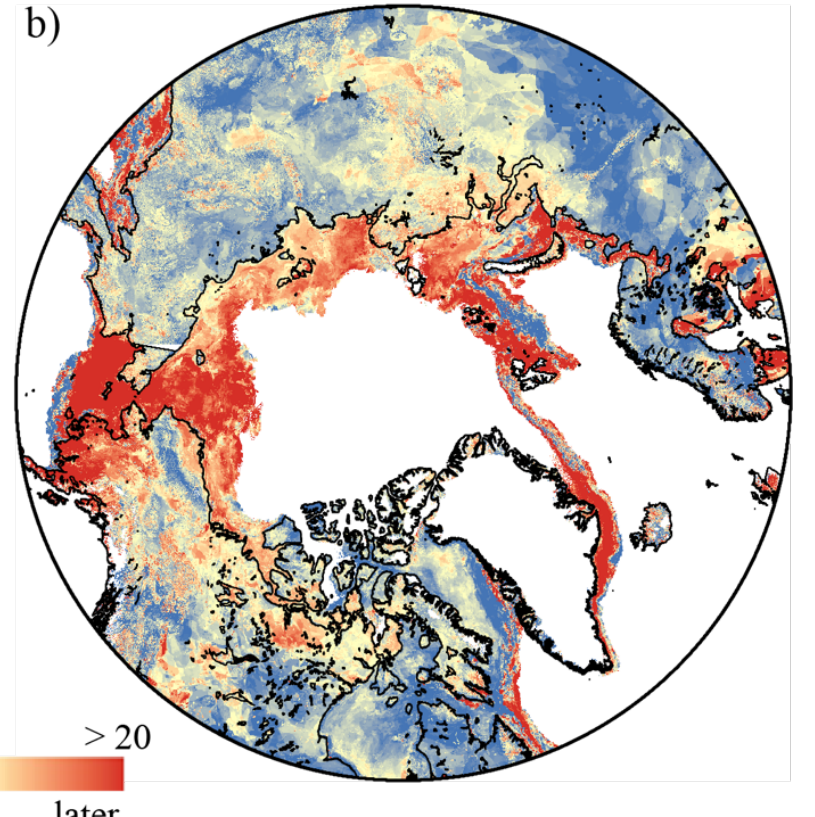

2004-2019
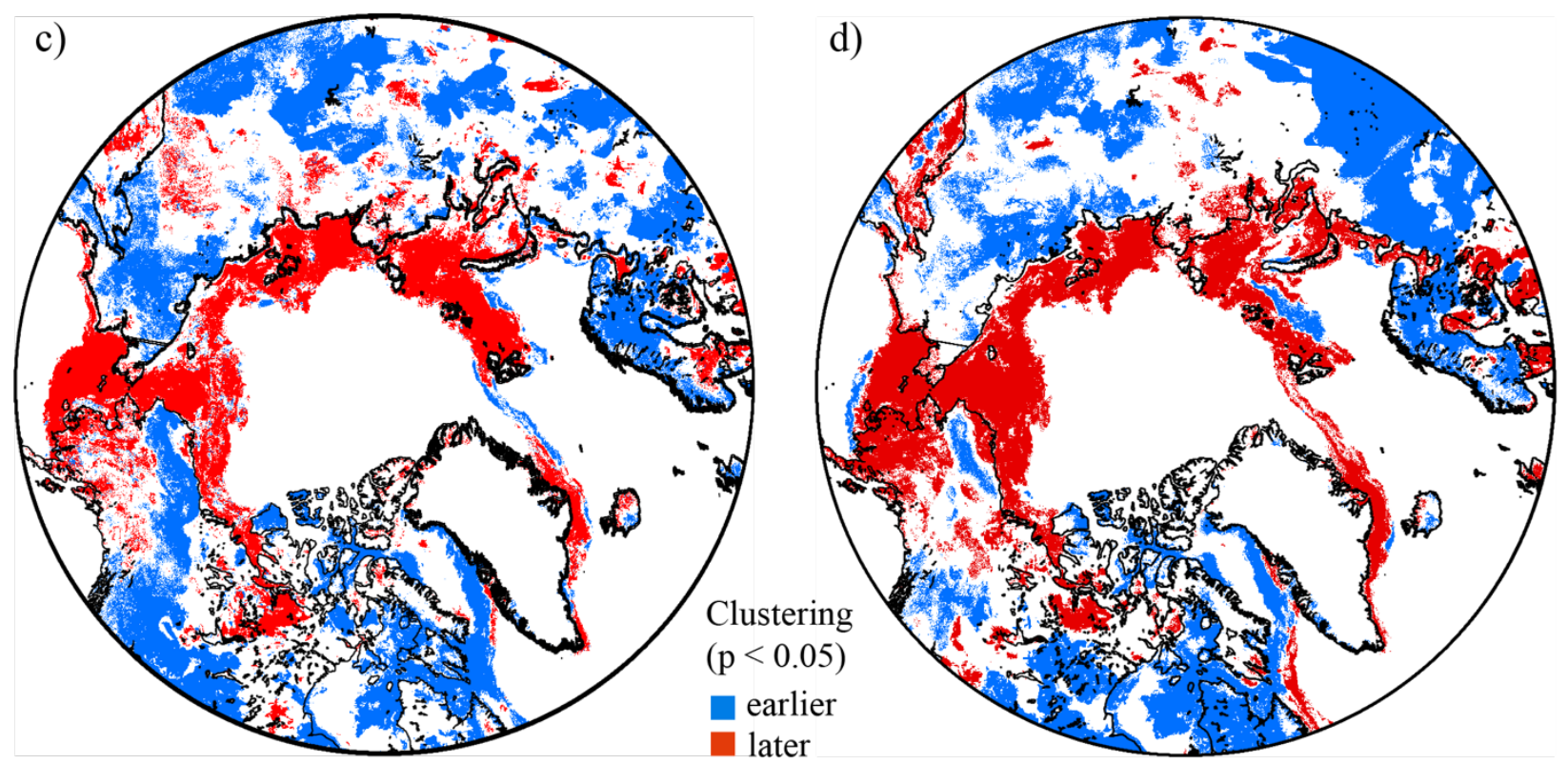

Figure 7. Trends in $4 \mathrm{~km}$ IMS (2004 - 2019) sea ice freeze onset (FO), first snow-on (first_soN), and lake ice freeze onset $\left(\mathrm{FO}_{\mathrm{L}}\right)(\mathrm{a})$, and sea ice continuous ice cover $\left(\mathrm{CIC}_{\mathrm{S}}\right)$, final snow-on (final_son), and lake ice continuous ice cover $\left(\mathrm{CIC}_{\mathrm{L}}\right)(\mathrm{b})$, significant trend clusters in FOs, $\mathrm{FO}_{\mathrm{L}}$ and first_son $(\mathrm{c})$, and significant trend clusters in $\mathrm{CIC}_{\mathrm{S}}, \mathrm{CIC}_{\mathrm{L}}$, and final_son (d). 
https://doi.org/10.5194/tc-2021-52

Preprint. Discussion started: 23 February 2021

(c) Author(s) 2021. CC BY 4.0 License.
The Cryosphere IEGU
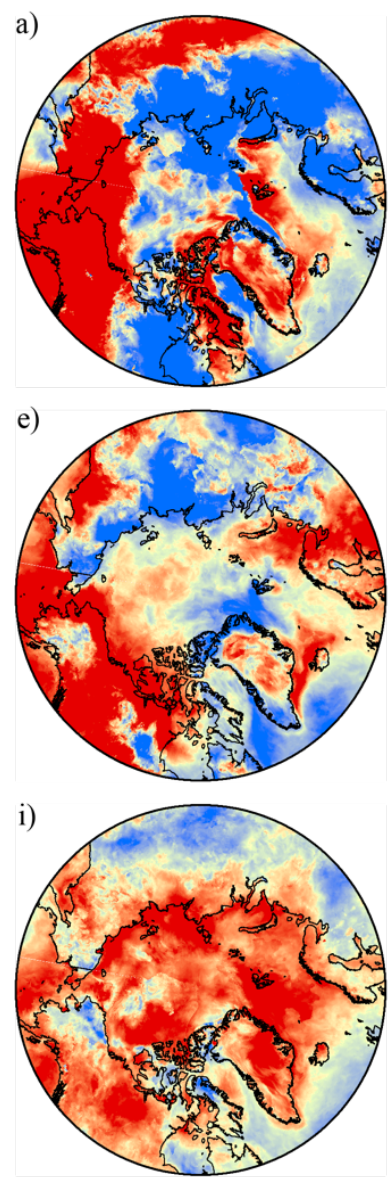
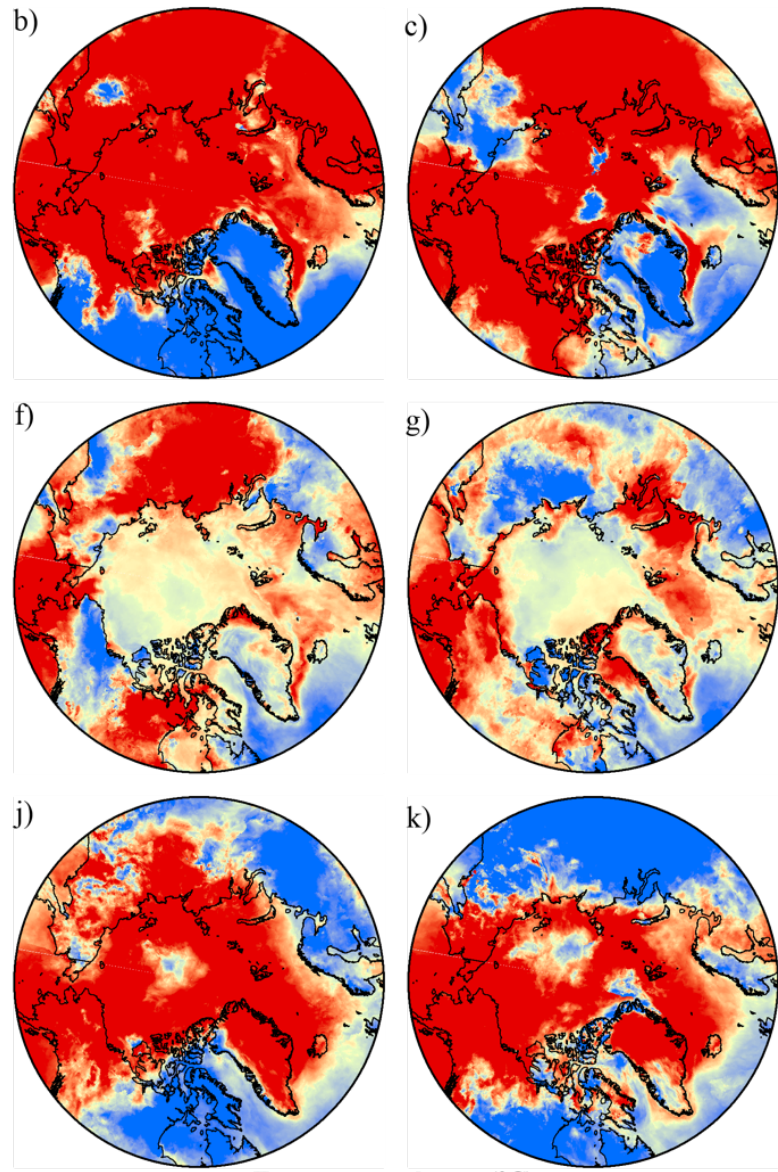

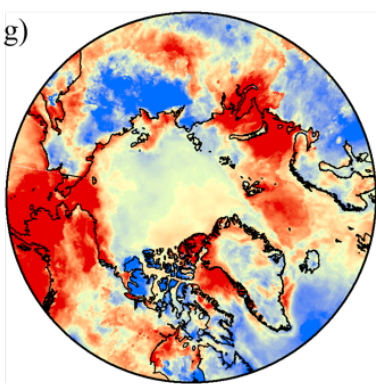

g)

k)

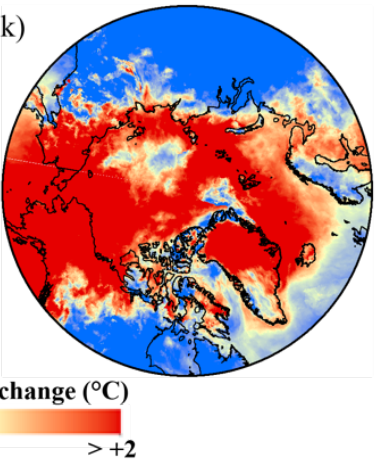

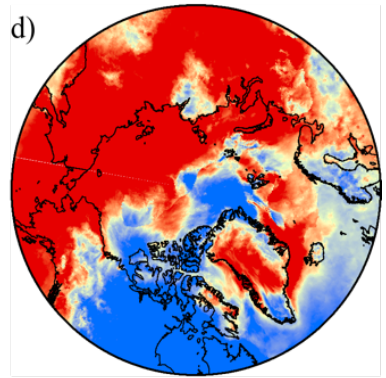

d)

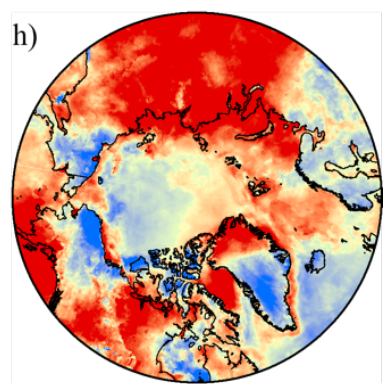

1)

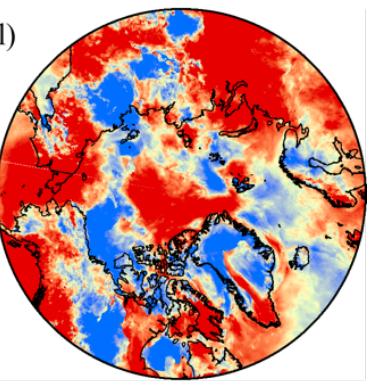

$\begin{array}{lcc}\text { Temperature change }\left({ }^{\circ} \mathrm{C}\right) \\ <-2 & 0 & >+2\end{array}$

Figure 8. Trends in monthly $2 \mathrm{~m}$ temperature from 2004 - 2019 in January (a), February (b), March (c), April (d), May (e), June (f), July (g), August (h), September (i), October (j), November (k), and December (l). 
https://doi.org/10.5194/tc-2021-52

Preprint. Discussion started: 23 February 2021

(C) Author(s) 2021. CC BY 4.0 License.

(c) (1)

695

Table 1. Sea ice, lake ice, and snow phenology parameters and definitions in this study.

\section{Parameter}

Definition

\begin{tabular}{|c|c|c|}
\hline $\begin{array}{l}\text { FOW }_{S} \\
\text { FOW }_{L}\end{array}$ & $\begin{array}{l}\text { First open water (sea ice) } \\
\text { First open water (lake ice) }\end{array}$ & The first change from ice to water for a given pixel \\
\hline $\begin{array}{l}\mathrm{WCI}_{\mathrm{S}} \\
\mathrm{WCI}_{\mathrm{L}}\end{array}$ & $\begin{array}{l}\text { Water clear of ice (sea ice) } \\
\text { Water clear of ice (lake ice) }\end{array}$ & $\begin{array}{l}\text { The last change from ice to water, signaling ice-free conditions for the remainder } \\
\text { of the season }\end{array}$ \\
\hline $\begin{array}{l}\mathrm{FO}_{\mathrm{S}} \\
\mathrm{FO}_{\mathrm{L}}\end{array}$ & $\begin{array}{l}\text { Freeze onset (sea ice) } \\
\text { Freeze onset (lake ice) }\end{array}$ & The first detection of ice for a given pixel \\
\hline $\begin{array}{l}\mathrm{CIC}_{\mathrm{S}} \\
\mathrm{CIC}_{\mathrm{L}}\end{array}$ & $\begin{array}{l}\text { Continuous ice cover (sea ice) } \\
\text { Continuous ice cover (lake } \\
\text { ice) }\end{array}$ & The date of the last change from water to ice \\
\hline first_s $\mathrm{S}_{\mathrm{OFF}}$ & First snow-off & The first change from snow-covered land to snow-free land for a given pixel \\
\hline final_soFf & Final snow-off & $\begin{array}{l}\text { The last change from snow-covered to snow-free land, signalling snow-free } \\
\text { conditions for the remainder of the season }\end{array}$ \\
\hline first_SON & First snow-on & The first change from snow-free land to snow-covered land \\
\hline final_SON & Final snow-on & The last change from snow-free to snow-covered land \\
\hline
\end{tabular}


https://doi.org/10.5194/tc-2021-52

Preprint. Discussion started: 23 February 2021

(C) Author(s) 2021. CC BY 4.0 License.

700 Table 2. Pan-Arctic Spearman rank correlations ( $\rho)$ for snow and sea ice phenology dates and monthly 2 m temperature from 1997 - 2019 using 24 km IMS. Months were selected for each phenology parameter based on mean phenology dates in Figure 3. * represents statistically significant correlations at the $95 \%$ confidence level.

\begin{tabular}{c|ll|ll|ll|ll}
\hline & \multicolumn{2}{|l}{ Sea Ice } & \multicolumn{2}{c|}{ Freeze } & \multicolumn{2}{c}{ Melt } & \multicolumn{2}{c}{ Freeze } \\
& \multicolumn{2}{|c}{ Melt } & \multicolumn{2}{|c|}{ Snow } \\
& FOWs & WCIs & FOs & CICs & first_SOFF & final_SOFF & first_sON & final_son \\
\hline Jan & - & - & 0.28 & 0.26 & - & - & 0.23 & 0.34 \\
Feb & - & - & 0.09 & 0.15 & - & - & - & - \\
Mar & -0.22 & -0.31 & 0.04 & -0.19 & -0.31 & -0.08 & - & - \\
Apr & $-0.50^{*}$ & $-0.57^{*}$ & 0.34 & 0.22 & -0.34 & -0.36 & - & - \\
May & -0.39 & -0.33 & - & - & -0.26 & -0.11 & - & - \\
Jun & $-0.60^{*}$ & $-0.60^{*}$ & - & - & $-0.46^{*}$ & -0.34 & - & - \\
Jul & $-0.58^{*}$ & $-0.57^{*}$ & - & - & $-0.49^{*}$ & -0.41 & - & - \\
Aug & -0.33 & -0.32 & - & - & -0.17 & -0.18 & 0.03 & -0.06 \\
Sep & $-0.69^{*}$ & $-0.60^{*}$ & 0.40 & 0.21 & - & - & 0.25 & 0.25 \\
Oct & - & - & $0.48^{*}$ & 0.41 & - & - & 0.28 & 0.41 \\
Nov & - & - & 0.19 & 0.14 & - & - & 0.06 & 0.08 \\
Dec & - & - & 0.00 & -0.05 & - & - & 0.16 & 0.10 \\
\hline
\end{tabular}


https://doi.org/10.5194/tc-2021-52

Preprint. Discussion started: 23 February 2021

(C) Author(s) 2021. CC BY 4.0 License.

705 Table 3. Pan-Arctic Spearman rank correlations ( $\rho)$ for snow and ice phenology dates using the $24 \mathrm{~km}(1997$ - 2019$)$ and $4 \mathrm{~km}$ (2004 - 2019) IMS products. * represents statistically significant correlations at the $95 \%$ confidence level.

\begin{tabular}{|c|c|c|}
\hline \multicolumn{3}{|c|}{ 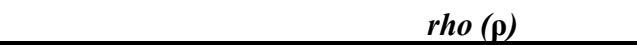 } \\
\hline \multicolumn{3}{|c|}{ First melt } \\
\hline & first $\mathrm{S}_{\mathrm{OFF}}$ & $\mathrm{FOW}_{\mathrm{L}}$ \\
\hline $\mathrm{FOW}_{\mathrm{S}}$ & $\begin{array}{l}0.38(24 \mathrm{~km}) \\
0.38(4 \mathrm{~km})\end{array}$ & $0.62 *(4 \mathrm{~km})$ \\
\hline $\mathrm{FOW}_{\mathrm{L}}$ & $0.55 *(4 \mathrm{~km})$ & - \\
\hline \multicolumn{3}{|c|}{ Final melt } \\
\hline & final_soFF & $\mathrm{WCI}_{\mathrm{L}}$ \\
\hline $\mathrm{WCI}_{\mathrm{S}}$ & $\begin{array}{l}0.46^{*}(24 \mathrm{~km}) \\
0.64 *(4 \mathrm{~km})\end{array}$ & $0.72 *(4 \mathrm{~km})$ \\
\hline $\mathrm{WCI}_{\mathrm{L}}$ & $0.51 *(4 \mathrm{~km})$ & - \\
\hline \multicolumn{3}{|c|}{ First Freeze } \\
\hline & first_s $\mathrm{S}_{\mathrm{ON}}$ & $\mathrm{FO}_{\mathrm{L}}$ \\
\hline $\mathrm{FO}_{\mathrm{S}}$ & $\begin{array}{l}0.15(24 \mathrm{~km}) \\
0.08(4 \mathrm{~km})\end{array}$ & $0.23(4 \mathrm{~km})$ \\
\hline $\mathrm{FO}_{\mathrm{L}}$ & $-0.27(4 \mathrm{~km})$ & - \\
\hline \multicolumn{3}{|c|}{ Final Freeze } \\
\hline & final_s $\mathrm{S}_{\mathrm{ON}}$ & $\mathrm{CIC}_{\mathrm{L}}$ \\
\hline $\mathrm{CIC}_{\mathrm{S}}$ & $\begin{array}{l}0.37(24 \mathrm{~km}) \\
0.24(4 \mathrm{~km})\end{array}$ & $0.37(4 \mathrm{~km})$ \\
\hline $\mathrm{CIC}_{\mathrm{L}}$ & $0.19(4 \mathrm{~km})$ & - \\
\hline
\end{tabular}


https://doi.org/10.5194/tc-2021-52

Preprint. Discussion started: 23 February 2021

(c) Author(s) 2021. CC BY 4.0 License.

Table 4. Regional analysis (see Figure 1) of the median trend strength (days/15years?) and direction (- earlier, + later) for all of the phenology parameters: First open water (FOW, subscript S denotes sea ice, L denotes Lake ice), Water clear of ice (WCI, subscript $S$ denotes sea ice, $L$ denotes Lake ice), Freeze onset (FO, subscript $S$ denotes sea ice, $L$ denotes Lake ice), Complete ice cover (CIC, subscript $S$ denotes sea ice, $L$ denotes Lake ice), first and final snow-off (_S Soff), first and final snow-on (_Son).

Sea Ice

\section{Canadian Arctic Region}

Canadian Arctic Archipelago

Hudson Bay

Baffin Bay

Davis Strait

Alaska/ Far East Russia Region

Beaufort Sea

Chukchi Sea

Bering Sea

Eurasia Region

Eastern Siberian Sea

Laptev Sea

Kara Sea

Barents Sea

Greenland Sea

Snow/Lake Ice

North American Arctic

Canada Mainland West

Northern QC

Alaska/ Far East Russia

Western Alaska

North Slope

Far East Russia

Nettlling Lake

Amadjuak Lake

Great Slave Lake

Great Bear Lake

Lake Hazen

Eurasia

Scandinavia/Northern Europe

NW Eurasia

Central Eurasia

NE Eurasia

Lake Ladoga*

Lake Onega

\begin{tabular}{rr|rr}
\hline \multicolumn{2}{c|}{ Melt } & \multicolumn{2}{c}{ Freeze } \\
FOW $_{\mathbf{S}}$ & WCI $_{\mathbf{S}}$ & FO $_{\mathbf{S}}$ & $\mathbf{C I C}_{\mathbf{S}}$ \\
\hline $\mathbf{+ 2}$ & $\mathbf{- 7}$ & $\mathbf{- 1 1}$ & $\mathbf{- 9}$ \\
-4 & -7 & -12 & -8 \\
+2 & -7 & -10 & -10 \\
-9 & -18 & -7 & -6 \\
+24 & +11 & -22 & -10 \\
$\mathbf{- 2 3}$ & $\mathbf{- 3 1}$ & $\mathbf{+ 8}$ & $+\mathbf{1 4}$ \\
-30 & -37 & +6 & +8 \\
-25 & -31 & +8 & +19 \\
-34 & -41 & +27 & +52 \\
$\mathbf{- 1 4}$ & $\mathbf{- 2 8}$ & +7 & $+\mathbf{1 0}$ \\
-15 & -24 & +5 & +7 \\
-11 & -28 & +8 & +8 \\
-16 & -32 & +7 & +10 \\
-15 & -34 & +16 & +13 \\
-13 & -25 & +2 & +15
\end{tabular}

\begin{tabular}{|c|c|c|c|c|c|c|c|}
\hline \multicolumn{4}{|c|}{ Melt } & \multicolumn{4}{|c|}{ Freeze } \\
\hline $\begin{array}{c}\text { First } \\
\mathrm{S}_{\mathrm{OFF}} \\
\end{array}$ & $\begin{array}{c}\text { Final } \\
\mathbf{S}_{\text {OFF }} \\
\end{array}$ & FOW $_{L}$ & $\mathbf{W C I}_{\mathbf{L}}$ & $\begin{array}{r}\text { First } \\
S_{\text {ON }} \\
\end{array}$ & $\begin{array}{r}\text { Final } \\
\mathbf{S}_{\mathrm{ON}} \\
\end{array}$ & FO $_{\mathrm{L}}$ & $\mathrm{CIC}_{\mathrm{L}}$ \\
\hline-8 & -6 & -4 & -4 & -8 & -3 & +2 & $\mathbf{0}$ \\
\hline-11 & -10 & -5 & -5 & -5 & -4 & +5 & +1 \\
\hline-7 & -5 & +9 & +9 & -8 & -16 & -4 & -2 \\
\hline-3 & 0 & -18 & -19 & -5 & +1 & +9 & +11 \\
\hline-17 & -15 & -22 & -27 & +3 & +22 & +33 & +25 \\
\hline-8 & -1 & +3 & +3 & -21 & 0 & -8 & -9 \\
\hline \multirow[t]{6}{*}{0} & 1 & $N A$ & $N A$ & -9 & -4 & $N A$ & $N A$ \\
\hline & & -3 & +2 & & & -3 & -1 \\
\hline & & -1 & 0 & & & +3 & +2 \\
\hline & & -6 & -4 & & & +3 & +1 \\
\hline & & -4 & -8 & & & +8 & +6 \\
\hline & & -1 & -4 & & & +3 & -11 \\
\hline 0 & 0 & -1 & -2 & -9 & -7 & +8 & +8 \\
\hline 0 & 0 & -1 & -1 & -13 & -9 & +28 & +19 \\
\hline+5 & +3 & +1 & -2 & -8 & -13 & -4 & -6 \\
\hline 0 & 0 & -7 & -9 & -9 & -4 & -2 & -4 \\
\hline \multirow[t]{3}{*}{-1} & -1 & +2 & +2 & -9 & -8 & -6 & -9 \\
\hline & & N/A & -9 & & & +13 & N/A \\
\hline & & -5 & -6 & & & +28 & +15 \\
\hline
\end{tabular}

\footnotetext{
* $\mathrm{FOW}_{\mathrm{L}}$ and $\mathrm{CIC}_{\mathrm{L}}$ are not included for Lake Ladoga as the lake did not fully freeze in several of the study years.
} 
https://doi.org/10.5194/tc-2021-52

Preprint. Discussion started: 23 February 2021

(c) Author(s) 2021. CC BY 4.0 License.

Table 5. Regional Spearman rank correlations ( $\rho$ ) for snow and ice phenology dates and monthly 2 m temperature from 2004 - 2019 using 4 km IMS. For sea ice, 'Canadian Arctic' includes Baffin Bay, Hudson Bay, and the CAA; 'Alaska/Far East Russia' includes Beaufort, Chukchi, and Bering seas; 'Eurasian Arctic' includes East Siberian, Laptev, Kara, Bering, and Greenland seas (See Figure 1). Months were selected for each phenology parameter based on mean phenology dates in Figure 3. * represents statistically significant correlations at the $95 \%$ confidence level.

\begin{tabular}{|c|c|c|c|c|c|c|}
\hline \multirow[t]{2}{*}{ Melt } & \multicolumn{2}{|c|}{ Canadian Arctic } & \multicolumn{2}{|c|}{ Alaska/Far East Russia } & \multicolumn{2}{|c|}{ Eurasian Arctic } \\
\hline & $\mathrm{FOW}_{\mathrm{S}}$ & $\mathrm{WCI}_{\mathrm{S}}$ & $\mathrm{FOW}_{\mathrm{S}}$ & $\mathrm{WCI}_{\mathrm{S}}$ & $\mathrm{FOW}_{\mathrm{S}}$ & $\mathrm{WCI}_{\mathrm{S}}$ \\
\hline Mar & -0.19 & -0.20 & -0.37 & $-0.55^{*}$ & -0.17 & -0.07 \\
\hline Apr & -0.41 & -0.40 & -0.11 & -0.19 & -0.43 & $-0.59 *$ \\
\hline May & -0.44 & $-0.61 *$ & -0.05 & 0.22 & -0.12 & -0.35 \\
\hline Jun & $-0.62 *$ & $-0.69 *$ & -0.20 & 0.05 & -0.06 & -0.44 \\
\hline Jul & $-0.55^{*}$ & $-0.67 *$ & -0.43 & -0.12 & 0.28 & -0.20 \\
\hline Aug & $-0.82 *$ & $-0.77 *$ & -0.50 & -0.22 & 0.43 & -0.03 \\
\hline Sep & $-0.70^{*}$ & $-0.56^{*}$ & $0.54 *$ & $0.67 *$ & 0.10 & -0.10 \\
\hline \multirow[t]{2}{*}{ Freeze } & \multicolumn{2}{|c|}{ Canadian Arctic } & \multicolumn{2}{|c|}{ Alaska/Far East Russia } & \multicolumn{2}{|c|}{ Eurasian Arctic } \\
\hline & $\mathrm{FO}_{\mathrm{S}}$ & $\mathrm{CIC}_{\mathrm{S}}$ & $\mathrm{FO}_{\mathrm{S}}$ & $\mathrm{CIC}_{\mathrm{S}}$ & $\mathrm{FO}_{\mathrm{S}}$ & $\mathrm{CIC}_{\mathrm{S}}$ \\
\hline Sep & $0.57 *$ & $0.64 *$ & -0.20 & -0.17 & 0.44 & -0.02 \\
\hline Oct & $0.58 *$ & $0.61 *$ & -0.24 & 0.02 & $0.57^{*}$ & 0.27 \\
\hline Nov & $0.82 *$ & $0.77 *$ & 0.36 & 0.33 & 0.35 & 0.13 \\
\hline Dec & $0.54 *$ & $0.70 *$ & -0.04 & -0.11 & 0.49 & 0.16 \\
\hline Jan & 0.15 & -0.22 & -0.18 & 0.03 & 0.22 & 0.08 \\
\hline Feb & $0.64 *$ & 0.50 & 0.29 & 0.34 & 0.26 & 0.12 \\
\hline Mar & $0.52 *$ & 0.29 & 0.29 & 0.37 & 0.12 & -0.27 \\
\hline Apr & 0.30 & 0.31 & -0.04 & -0.19 & 0.07 & 0.20 \\
\hline
\end{tabular}

Snow and Lake Ice

\begin{tabular}{|c|c|c|c|c|c|c|c|c|}
\hline \multirow[t]{2}{*}{ Melt } & \multicolumn{4}{|l|}{ Eurasia } & \multicolumn{4}{|c|}{ North America } \\
\hline & first_SOFF & final_SOFF & $\mathrm{FOW}_{\mathrm{L}}$ & $\mathrm{WCI}_{\mathrm{L}}$ & first_SOFF & final_SoFF & $\mathrm{FOW}_{\mathrm{L}}$ & $\mathrm{WCI}_{\mathrm{L}}$ \\
\hline Mar & 0.12 & 0.15 & -0.25 & -0.18 & $-0.52 *$ & -0.40 & -0.33 & -0.29 \\
\hline May & $-0.91 *$ & $-0.77 *$ & -0.19 & -0.43 & $-0.62 *$ & $-0.55^{*}$ & -0.32 & -0.33 \\
\hline Jun & -0.40 & -0.32 & 0.12 & -0.07 & -0.39 & -0.07 & $-0.53^{*}$ & $-0.55^{*}$ \\
\hline Aug & 0.28 & 0.18 & -0.30 & -0.12 & -0.15 & -0.14 & $-0.76^{*}$ & $-0.76^{*}$ \\
\hline \multirow[t]{2}{*}{ Freeze } & \multicolumn{4}{|l|}{ Eurasia } & \multicolumn{4}{|c|}{ North America } \\
\hline & first_s $\mathrm{S}_{\mathrm{ON}}$ & final_s $\mathrm{S}_{\mathrm{ON}}$ & $\mathrm{FO}_{\mathrm{L}}$ & $\mathrm{CIC}_{\mathrm{L}}$ & first_s $\mathrm{S}_{\mathrm{ON}}$ & final_s $\mathrm{SN}_{\mathrm{N}}$ & $\mathrm{FO}_{\mathrm{L}}$ & $\mathrm{CIC}_{\mathrm{L}}$ \\
\hline Aug & 0.03 & 0.37 & - & - & $0.53^{*}$ & 0.44 & - & - \\
\hline Sep & 0.43 & $0.58 *$ & 0.30 & 0.27 & $0.77 *$ & 0.45 & 0.14 & 0.18 \\
\hline Jan & $0.84 *$ & $0.81 *$ & -0.25 & -0.16 & 0.14 & 0.08 & 0.05 & 0.15 \\
\hline
\end{tabular}


https://doi.org/10.5194/tc-2021-52

Preprint. Discussion started: 23 February 2021

(c) Author(s) 2021. CC BY 4.0 License.

(c) (i)

Feb

0.39

0.06

0.09 